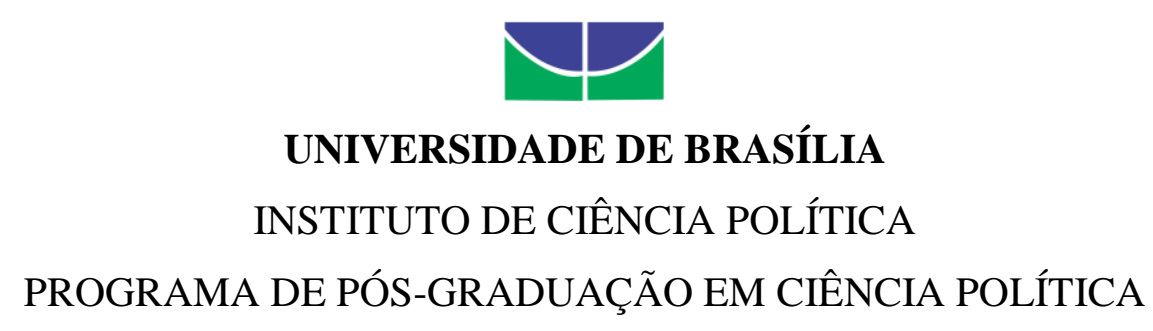

RIGIDEZ OU FLEXIBILIDADE GOVERNAMENTAL? DISCURSOS ANTI-CORRUPÇÃO E PRÓ-EFICIÊNCIA SOBRE CONTRATAÇÕES COM ORÇAMENTO SIGILOSO

Otávio Ventura 
UNIVERSIDADE DE BRASÍLIA

INSTITUTO DE CIÊNCIA POLÍTICA

PROGRAMA DE PÓS-GRADUAÇÃO EM CIÊNCIA POLÍTICA

\title{
RIGIDEZ OU FLEXIBILIDADE GOVERNAMENTAL? \\ DISCURSOS ANTI-CORRUPÇÃO E PRÓ-EFICIÊNCIA SOBRE \\ CONTRATAÇÕES COM ORÇAMENTO SIGILOSO
}

\author{
Otávio Ventura
}

Dissertação de mestrado apresentada ao Programa de Pós-Graduação em Ciência Política, da Universidade de Brasília, como parte dos requisitos para a obtenção do grau de Mestre em Ciência Política, área de concentração Política e Instituições.

Orientador: Prof. Dr. Alexandre Araújo Costa

Brasília 
RIGIDEZ OU FLEXIBILIDADE GOVERNAMENTAL? DISCURSOS ANTI-CORRUPÇÃO E PRÓ-EFICIÊNCIA SOBRE CONTRATAÇÕES COM ORÇAMENTO SIGILOSO

\section{BANCA EXAMINADORA}

Dr. Alexandre Araújo Costa (UnB)

Orientador

Dra. Rebecca Neaera Abers (UnB) Membro interno

Dra. Ana Cláudia Farranha (UnB)

Membro externo

Dr. Pablo Holmes (UnB)

Suplente 
A Geraldo, Leonilda, José e Teresinha. 


\section{AGRADECIMENTOS}

À minha companheira de vida, Laina, por ter me encorajado a tentar o Mestrado.

À minha família, por sempre acreditar e confiar em mim nos meus erros e acertos.

Aos amigos de longa data, pela cumplicidade irrestrita e atemporal.

Aos amigos burocratas, por me ajudarem a pensar nas perguntas certas.

Ao orientador da pesquisa, pelos pacientes ensinamentos.

Aos membros da banca, pelo precioso tempo de vocês.

Aos professores do IPOL, pelos sábios e necessários puxões de orelha.

Aos colegas de turma no IPOL, pelas valiosas discussões em sala de aula.

Aos chefes no trabalho, pela compreensão das ausências por causa dos estudos.

E à minha cachorrinha, $\mathrm{M}$, por sempre me lembrar que a boa alegria é a mais simples. 


\section{RESUMO}

Os governantes eleitos enfrentam, de um lado, a pressão para serem eficientes, e de outro, as amarras dos mecanismos de freios e contrapesos estatais. Esta tensão entre eficiência e controle é muito clara na institucionalidade das contratações públicas, onde o Estado se relaciona diretamente com o mercado, o que exige controle, e por meio da qual o Estado faz muitas entregas à população, o que demanda eficiência. As contratações com orçamento sigiloso são aquelas onde os licitantes não sabem o valor que o Estado está disposto a gastar no negócio, de modo que devem elaborar suas propostas sem ter acesso a essa informação. Este tipo de contratação surgiu na institucionalidade brasileira em três momentos. O propósito geral desta pesquisa foi investigar a relação entre discursos anti-corrupção e pró-eficiência sobre orçamento sigiloso nestes três momentos para tentar entender como os discursos que afirmam o primado de uma das dimensões consideram a outra. Foi utilizada a plataforma do Institucionalismo Discursivo para analisar uma variedade de discursos de políticos governistas, políticos oposicionistas e agentes de órgãos de controle. Os resultados mostraram que a tensão discursiva entre a necessidade de eficiência estatal e as amarras dos mecanismos de freios e contrapesos é muito ativa, embora resida em nível bem mais sutil que o suposto inicialmente pela pesquisa. As ideias pró-eficiência e anti-corrupção parecem ser abstratas demais para entrarem em confronto direto, de modo que os agentes não chegaram a declarar o primado de uma ou outra dimensão. Entretanto, eles parecem ter privilegiado uma delas quando defenderam ideias mais específicas em seus discursos. Aquele que prioriza uma ideia específica como a rigidez de regras pode estar comprometendo a eficiência, ainda que se declare favorável a ela. Do mesmo modo, aquele que enfatiza uma ideia específica como a flexibilidade pode estar dificultando o combate à corrupção, ainda que discursivamente defenda este combate.

Palavras-chaves: administração pública, eficiência, freios e contrapesos, controle, corrupção, orçamento sigiloso, contratações públicas, pregão, RDC, institucionalismo discursivo, ideias, discursos. 


\section{RESUMEN}

Los gobernantes electos enfrentan, por un lado, la presión para ser eficiente, y por el otro, las amarras de los mecanismos de frenos y contrapesos estatales. Esta tensión entre eficiencia y control es muy clara en el marco institucional de las contrataciones públicas, donde el Estado está directamente relacionado con el mercado, lo que requiere control, y través del cual el Estado hace muchas entregas a la población, lo que exige eficiencia. Los contratos con presupuesto confidencial son aquellos en los que los postores no saben el valor que el Estado está dispuesto a gastar en el negocio, por lo que deben preparar sus propuestas sin tener acceso a esta información. Este tipo de contrato se ha convertido en las instituciones brasileñas en tres ocasiones. El objetivo general de esta investigación fue investigar la relación entre discursos anti-corrupción y pro-eficiencia del presupuesto confidencial en estos tres veces para entender cómo los discursos que afirman la primacía de una de las dimensiones consideran la otra. La plataforma del Institucionalismo Discursivo fue utilizada para analizar una variedad de discursos de los políticos a favor del gobierno, políticos de la oposición y los agentes de los órganos de supervisión. Los resultados mostraron que la tensión discursiva entre la necesidad de eficiencia y los lazos de los mecanismos de frenos y contrapesos es muy activa, pero se encuentra en nivel mucho más sutil que supuesto inicialmente por la encuesta. Ideas pro-eficiencia y anti-corrupción parecen ser demasiado abstractas para entrar en confrontación directa, por lo que los agentes no vienen a declarar la primacía de una u otra dimensión. Sin embargo, parecen haber favorecido a uno de ellas cuando defendían ideas más específicas en sus discursos. Uno que da prioridad a una idea específica como la rigidez de regras puede comprometer la eficiencia, aunque se declaran a favor de ella. Del mismo modo, uno que hace énfasis en una idea específica como la flexibilidad puede estar obstaculizando la lucha contra la corrupción, aunque discursivamente defienda esta lucha.

Palabras clave: administración pública, eficiencia, frenos y contrapesos, control, corrupción, presupuesto confidencial, contrataciones públicas, Institucionalismo Discursivo, ideas, discursos. 


\begin{abstract}
Elected leaders face, on the one hand, the pressure to be efficient, on the other, the bonds of a system of checks and balances. This tension between efficiency and control becomes clearer in public contracting processes, where the State is directly related to the market, which requires control, and through which the State delivers many results, which demands efficiency. Contracts with confidential budget are those where competitors do not know the value that the State is willing to spend in a business transaction, so they should prepare their proposals without having access to this particular information. This type of contract has emerged in Brazilian institutions on three different occasions. The general purpose of this research was to investigate the relationship between anti-corruption and pro-efficiency discourses about confidential budget on these three occasions in order to understand how discourses that declare primacy of one dimension consider the other. The Discursive Institutionalism platform was applied to analyze a variety of discourses from pro-government politicians, opposition politicians and agents from control agencies. Results showed that the discursive tension between the need for efficiency and the bonds of checks and balances is very active, but lies in a much subtler level as initially supposed. Pro-efficiency and anticorruption ideas seem to be too abstract to come into direct confrontation, so that agents do not come to declare primacy of one or another. However, they seem to have favored one of them when they advocated more specific ideas in their discourses. One who prioritizes a specific idea as rule rigidity may be compromising efficiency, although one declares in favor of it. Similarly, one who emphasizes on a specific idea as flexibility may be obstructing fight against corruption, although discursively defend it.
\end{abstract}

Keywords: public management, efficiency, checks and balances, control, corruption, confidential budget, public contracting, Discursive Institutionalism, ideas, discourses. 


\section{SUMÁRIO}

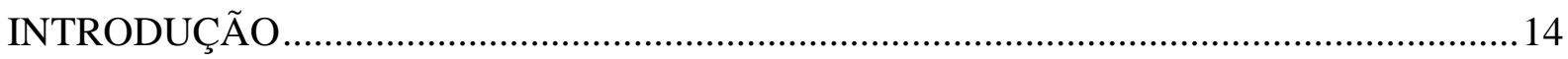

PARTE I: REFERENCIAL METODOLÓGICO E TEÓRICO ..............................................20

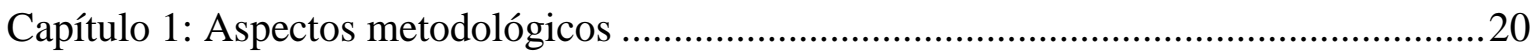

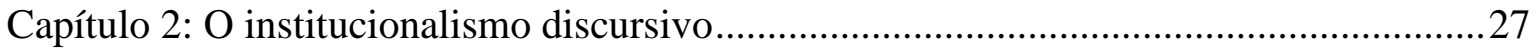

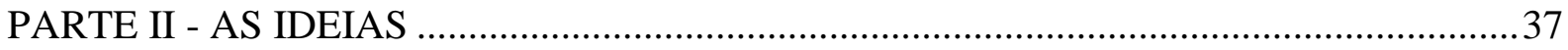

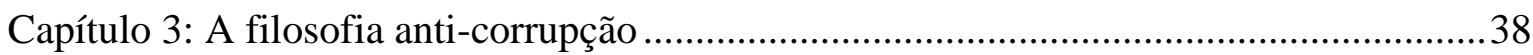

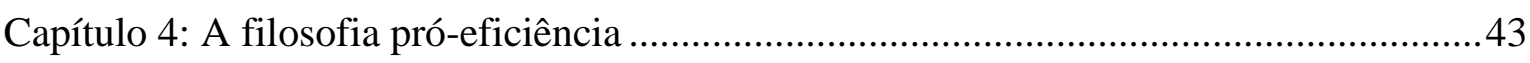

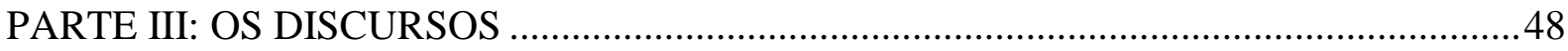

Capítulo 5: O orçamento sigiloso restrito à Anatel a partir de 1997 ...................................48

Capítulo 6: O orçamento sigiloso no Pregão a partir de 2000 ..............................................57

Capítulo 7: O orçamento sigiloso no RDC a partir de 2011 ..............................................67

DISCUSSÃO DOS RESULTADOS E CONCLUSÃO .................................................... 79

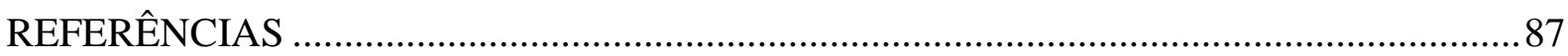




\section{LISTA DE SIGLAS}

ADI - Ação Direta de Inconstitucionalidade

AGU - Advocacia-Geral da União

Anatel - Agência Nacional de Telecomunicações

$\mathrm{CC}-$ Casa Civil

DEM - Democratas

Enap - Escola Nacional de Administração Pública

EC - Emenda Constitucional

ID - Institucionalismo Discursivo

IH - Institucionalismo Histórico

Infraero - Empresa Brasileira de Infraestrutura Aeroportuária

IR - Institucionalismo da Escolha Racional

IS - Institucionalismo Sociológico

LGT - Lei Geral de Telecomunicações

MC - Ministério das Comunicações

MPOG - Ministério do Planejamento, Orçamento e Gestão

MPV - Medida Provisória

MRE - Ministério das Relações Exteriores

MS - Ministério da Saúde

OCDE - Organização para a Cooperação e Desenvolvimento Econômico

PCdoB - Partido Comunista do Brasil

PPP - Parceria Público-Privada

PPS - Partido Popular Socialista

PDT - Partido Democrático Trabalhista

PSB - Partido Socialista Brasileiro 
PSDB - Partido da Social Democracia Brasileira

PT - Partido dos Trabalhadores

RDC - Regime Diferenciado de Contratações Públicas

SAJ - Subchefia de Assuntos Jurídicos

Serpro - Serviço Federal de Processamento de Dados

STF - Supremo Tribunal Federal

TCU - Tribunal de Contas da União 


\section{LISTA DE TABELAS}

Tabela 01 - Esquema do material de pesquisa utilizado...................................................24

Tabela 02 - Modelo de ficha analítica de discurso ................................................................26

Tabela 03 - Tipos de ideia segundo grau de generalidade e conteúdo.....................................33

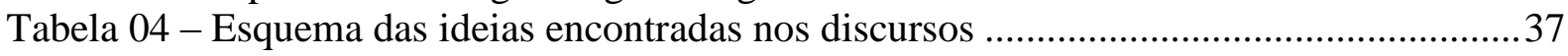

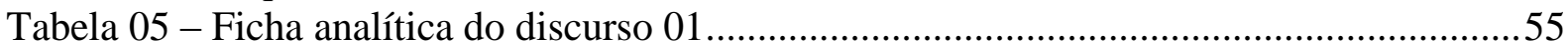

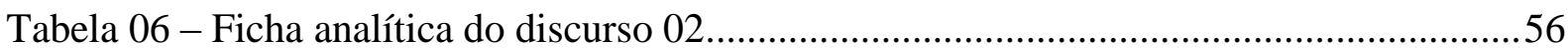

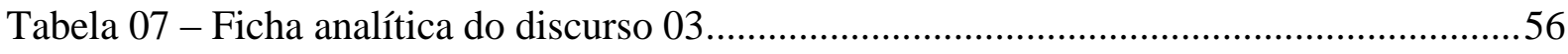

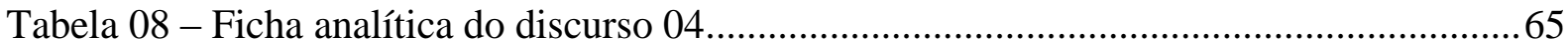

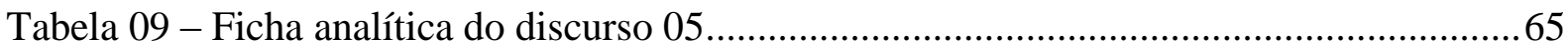

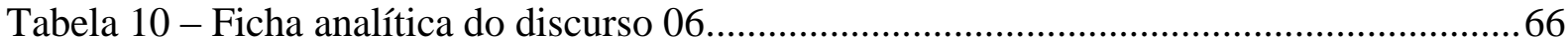

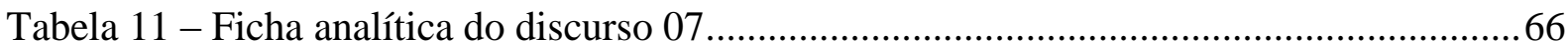

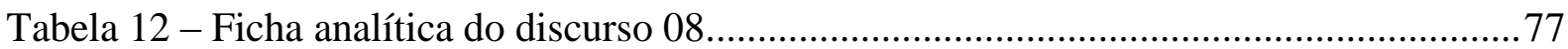

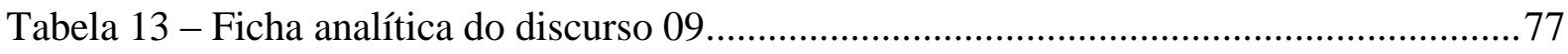

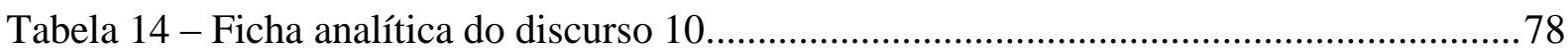

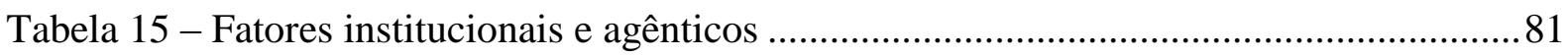

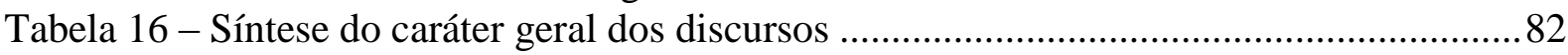




\section{INTRODUÇÃO}

Em contexto democrático, é raro que um governante não sinta, de um lado, a pressão para ser eficiente, e de outro, as amarras dos mecanismos de freios e contrapesos estatais. É compreensível que as pessoas exijam que os governantes operem o Estado com o máximo de eficiência, realizando as suas funções com o mínimo possível de recursos. Também é natural que as pessoas cobrem deles uma postura republicana, sem desvios éticos e com estrita observância da lei, dado não apenas o risco constante de atuação oportunista, corrupta, mas também em função de que uma sociedade democrática tende a estabelecer complexos processos de tomada de decisão, em que seja garantida a potencial influência de todos os atores e grupos interessados.

Uma análise preliminar nos permitiu observar que parte significativa dessa tensão entre eficiência e controle ${ }^{1}$ surge no ambiente das contratações públicas. Não é incomum que problemas contratuais causem atrasos em obras públicas, expondo falhas de eficiência dos governos. E também não é raro que escândalos de corrupção estejam ligados a contratos firmados entre Estado e empresas, revelando falhas de controle. Recentemente, duas grandes ondas de protestos no Brasil guardam alguma relação com deficiência de eficiência ou de controle em contratação pública. Nos movimentos de junho de 2013, uma das principais bandeiras era a melhoria da eficiência no transporte público, um setor que opera largamente sob a égide das contratações públicas, seja de serviços de transporte, seja de obras de infraestrutura de transporte. Já nos protestos após as eleições presidenciais de 2014, uma importante reivindicação era o combate à corrupção, com forte inspiração na Operação LavaJato, da Polícia Federal, que inclui investigações de artifícios utilizados durante décadas por grandes empresas para conseguir contratos com organizações públicas.

O conflito entre as dimensões de eficiência e controle poderia conduzir a um discurso fundado na ideia de equilíbrio, mas o que observamos de fato é que essa tensão tem sido apropriada politicamente por discursos que parecem privilegiar demasiadamente um desses polos. De um lado, existe um forte discurso anti-corrupção que aparentemente não leva devidamente em conta os imperativos de eficiência. De outro, existe um forte discurso próeficiência que aparentemente não leva devidamente em conta os imperativos de controle. $\mathrm{O}$ propósito geral desta pesquisa consiste em investigar a relação entre esses discursos,

\footnotetext{
${ }^{1}$ É importante esclarecer desde o início que neste trabalho empregaremos o termo controle em sentido amplo, abrangendo os mecanismos de freios e contrapesos estatais em geral.
} 
buscando avaliar se esse diagnóstico de polarização é correto, a partir de uma análise voltada a compreender como os propagadores do discurso anti-corrupção consideram a eficiência e como os propagadores do discurso pró-eficiência consideram o controle.

\section{A tensão entre as dimensões de eficiência e controle}

A atual Constituição brasileira organiza o poder estatal em três ramos, distribui autonomia política a três esferas federativas e, na maioria dos casos, condiciona o acesso ao poder a processos eleitorais periódicos. Ela impõe aos governantes a observância de objetivos e princípios específicos e ordena que o Estado ofereça uma vasta gama de direitos e garantias. E determina que tudo isso funcione com eficiência.

Observado isoladamente, este último comando parece exigir do Estado brasileiro que todas as suas atividades sejam feitas com a máxima eficiência, de modo que toda a estrutura de poder deveria ser (re)organizada para isso. Face a um contexto político e econômico que muda rapidamente, tanto no plano interno como no plano externo, um Estado eficiente deveria ser capaz de tomar decisões com grande rapidez, flexibilidade e adaptabilidade. No entanto, a celeridade decisória parece dialogar melhor com estruturas centralizadas de tomada de decisão, de modo que qualquer mecanismo que distribua poder decisório parece comprometer, em algum grau, a eficiência do sistema administrativo, na medida em que aumentaria o tempo e os custos de cada decisão. Não é por acaso que organizações que perseguem acima de tudo a extrema eficiência tendem a adotar estruturas altamente centralizadas e concentradoras de poder, como os comandos de guerra, as grandes corporações capitalistas ou os estados totalitários.

Apesar da previsão constitucional do princípio administrativo da eficiência, a ordem política brasileira não é organizada puramente em função da garantia da otimização da eficiência produtiva e administrativa. Temos o princípio da separação dos poderes, a autonomia política das três esferas e a consulta periódica às urnas, dentre muitos outros mecanismos, que funcionam como balanços e contrapesos de poder. Tais elementos são justificados a partir de valores democráticos e republicanos, cuja função é basicamente a de impedir a concentração de poder e que, nessa medida, operam em sentido contrário à eficiência estrita. Parte relevante dos esforços deve ser deslocada para a construção de alianças, para o diálogo com as diferenças, para a coordenação de diversos núcleos de poder que precisam ser ouvidos e podem comprometer o andamento das políticas desejadas pelos 
governantes. Sempre é possível que a falta de coordenação conduza a impasses, a demoras e, no limite, a um grau de inércia que pode ser perigoso para a própria estabilidade do sistema.

Nesse contexto, parece emergir uma constante tensão ${ }^{2}$ entre a legítima pretensão de eficiência com a legítima pretensão de controle. Essa tensão pode ser produtiva, mas ela também pode conduzir a situações indesejáveis, quando existe um desequilíbrio muito grande entre esses polos. Empregar parcela expressiva dos recursos públicos no próprio controle da atividade estatal pode comprometer demasiadamente a eficiência. De forma análoga, quando os recursos voltados ao controle são escassos, há risco de comprometimento da atuação republicana.

\section{Definindo o objeto: os discursos sobre inovações relativamente ao regime geral}

O ambiente institucional das contratações públicas nos parece ser suficientemente propício para se estudar a relação entre discursos anti-corrupção e discursos pró-eficiência. É por meio das contratações públicas que o Estado se relaciona com agentes de mercado, o que exige controle, e também é por meio delas que boa parcela das ações públicas são entregues à população, o que demanda eficiência. Entretanto, esta é uma institucionalidade complexa, com um vasto conjunto de regras e agentes interagindo de formas muito variadas.

No Brasil, existe mais de um regime de contratação pública. O mais tradicional deles é disciplinado pela Lei $n^{\circ}$ 8.666/1993, chamada de Lei Geral por ter sido editada pela União no exercício de sua competência privativa para legislar sobre "normas gerais de licitações e contratação", nos termos da CF, art. 22, XXVII. Essa Lei é caracterizada por Rosilho (2011) como maximalista por tentar detalhar exaustivamente todo o processo de contratação e criticada por Sunfeld (2015) por ser exagerada e distorcida, amarrando demais a Administração a soluções legais prévias. Após a promulgação da Lei Geral, leis específicas criaram uma nova modalidade licitatória (o Pregão, instituído pela Lei $n^{\circ} 10.520 / 2002$ ) e instituíram diversos regimes paralelos de contratação, todos sob a justificativa de dotar as contratações públicas de mais agilidade e eficiência. Dentre eles podem ser citados o regime de Concessões (Leis 8.987/1995 e 9.074/1995), o sistema específico de contratos simplificados para a Petrobras (art. 67 da Lei $n^{\circ}$ 9.748/1997 e Decreto $n^{\circ} 2.745 / 1998$ ), as Parcerias Público-Privadas - PPP (Lei no 11.079/2004) e o Regime Diferenciado de

\footnotetext{
${ }^{2}$ Enfatizar a relação entre eficiência e controle não significa assumir que estas dimensões funcionam, cada uma, de forma ideal. Ao contrário, elas mesmas podem estar contaminadas por uma série de disfunções internas, as quais não são objeto específico do presente estudo.
} 
Contratações Públicas - RDC (Lei nº 14.462/2011), todos simultaneamente vigentes nos dias de hoje. (PESSOA NETO e CORREIA, 2015)

As estratégias utilizadas por esses regimes particulares muitas vezes são convergentes, o que faz com que eles compartilhem algumas das características que os diferenciam do regime comum. Enquanto a Lei Geral estabelece que somente serão julgadas propostas de concorrentes habilitados, os novos regimes tipicamente estabelecem uma fase de habilitação posterior ao julgamento das propostas, como é o caso do Pregão, da Concessão e da PPP, além do RDC. As inovações no Pregão, que se tornou a modalidade preponderante de licitação, e a introdução do RDC conferiram uma amplitude muito maior ao mecanismo de registro de preços, que na Lei Geral era circunscrito às concorrências públicas. A contratação integrada já constava no regime de Concessões, e depois foi incorporada no RDC. O orçamento sigiloso hoje é compartilhado pelo Pregão e pelo RDC. (PESSOA NETO e CORREIA, 2015)

Como essas inovações tipicamente envolvem uma justificação argumentativa expressa, consideramos que a análise dos debates envolvidos na formulação e na implementação desses novos regimes é um espaço privilegiado para a compreensão das tensões entre as dimensões de eficiência e controle. Ao focar a pesquisa nos discursos acerca das referidas inovações procedimentais, pelo menos dois tipos de abordagens diferentes surgiam como possibilidades de recorte. Uma delas seria fazer um estudo mais geral focado nos diversos regimes de contratação, buscando captar os discursos que giram em torno deles. A outra seria fazer um estudo focado em determinados mecanismos destes regimes, buscando compreender discursos sobre as estratégias adotadas. A segunda perspectiva pareceu mais promissora porque a análise de uma estratégia transversal, que é usada por vários regimes, possibilita inclusive a análise comparativa dos modos como os discursos que estão ligados a elas ocorrem nos debates acerca dos diferentes regimes de contratação.

\section{Recorte do objeto de pesquisa: o orçamento sigiloso}

Dentre os mecanismos discutidos, o orçamento sigiloso se mostrou um objeto de pesquisa particularmente interessante porque foi um dos mais polêmicos no âmbito da formulação do RDC, além de ter sido objeto de constante disputa interpretativa quando já existia no âmbito do Pregão. Trata-se de uma inovação introduzida em 1997 no âmbito do regime próprio de contratação da Agência Nacional de Telecomunicações - Anatel e posteriormente adotada em outros regimes. 
A lógica do orçamento sigiloso é simples: em licitações cujo orçamento estimado é divulgado, a informação pode ser levada em consideração pelos interessados ao formular as suas propostas, de modo que é possível que isso acabe influenciando nos valores ofertados por eles. Já em contratações com orçamento sigiloso, os licitantes não sabem previamente o quanto a Administração pretende gastar no negócio, de modo que eles precisam formular as suas propostas sem essa informação. O sigilo da estimativa orçamentária é adotado por regras de contratações na Europa ${ }^{3}$ e nos Estados Unidos $^{4}$, além de ser recomendado pela divisão anti-cartéis ${ }^{5}$ da $\mathrm{OCDE}^{6}$.

A vantajosidade do orçamento sigiloso ainda não é ponto consensual na literatura brasileira. Os seus defensores argumentam que a incerteza sobre os valores que a Administração pretende gastar induz os participantes a oferecerem propostas melhores, mitigando riscos de conluios. Além disso, afirmam que o desconhecimento do valor de referência estimula os licitantes a estudar e conhecer melhor o objeto contratado. Argumentam ainda que o preço ofertado passa a ser de responsabilidade exclusiva do participante, não podendo este alegar que foi induzido a ofertar preço inexequível pela Administração. Por fim, justificam que o orçamento estimado pela Administração estará sempre à disposição dos órgãos de controle e que é tornado público ao fim da licitação, o que caracterizaria na verdade um sigilo temporário do orçamento, e não um orçamento sigiloso em si. (PESSOA NETO e CORREIA, 2015)

Por outro lado, os críticos do orçamento sigiloso alertam sobre o risco de vazamento seletivo do orçamento, possibilitando o favorecimento de um licitante específico. Além disso, há a crítica de que eventuais revisões do orçamento sigiloso durante a licitação podem favorecer ou prejudicar um determinado licitante, podendo qualificar ou afastar a sua proposta. Outra crítica se refere ao risco de fracasso de licitações onde a estimativa de preços da Administração seja baixa demais, o que não aconteceria se a estimativa fosse pública, dado que os valores poderiam ser questionados pelos licitantes, levando a eventuais revisões. Por fim, há a crítica de que o sigilo do orçamento fere o princípio constitucional da publicidade. (PESSOA NETO e CORREIA, 2015)

Diante de todos estes fatos interessantes, decidimos organizar a pesquisa a partir dos discursos sobre contratações com orçamento sigiloso. O surgimento deste mecanismo nas

\footnotetext{
${ }^{3}$ Diretiva 2004/18 do Parlamento Europeu.

${ }^{4}$ Item 36.2 do Regulamento Federal de Aquisições Públicas dos Estados Unidos.

${ }^{5}$ Documento disponível em http://www.oecd.org/daf/competition/cartels/44162082.pdf.

${ }^{6}$ Organização para a Cooperação e o Desenvolvimento Econômico.
} 
regras brasileiras de contratação aconteceu em três momentos, cada um correspondente a um regime distinto. Primeiramente, ele surgiu em 1997 no regime próprio de contratações da Anatel. Depois, apareceu no âmbito do Pregão, criado em 2000 na esfera federal e estendido em 2002 para todos os entes nacionais. Por último, o orçamento sigiloso surgiu em 2011 no âmbito do RDC. Conforme será detalhado mais adiante, a pesquisa está organizada de modo a captar discursos sobre o orçamento sigiloso nesses três momentos.

Para os fins desta pesquisa, o ambiente público será delimitado pelo contexto institucional das contratações com orçamento sigiloso e o horizonte temporal será relativo a três momentos em que foi discutida a sua implantação ou ampliação. O ângulo de análise será o embate discursivo entre promoção da eficiência e combate à corrupção, travado por políticos governistas, políticos oposicionistas e agentes de órgãos de controle, buscando responder à seguinte pergunta: como os discursos que afirmam o primado de uma dessas dimensões levam a outra em consideração? 


\section{PARTE I: REFERENCIAL METODOLÓGICO E TEÓRICO}

\section{Capítulo 1: Aspectos metodológicos}

\section{A escolha pela abordagem qualitativa}

Um dos debates mais calorosos relativos à metodologia das ciências sociais se refere às possibilidades e limites dos diferentes métodos disponíveis para o pesquisador. Em um seminário ministrado em outubro de 1987 na Ecole de Hautes Etudes en Sciences Sociales, Pierre Bourdieu (2007) criticava a pressuposição de supremacia de um tipo de método sobre todos os outros, algo que ele chamava de monoteísmo metodológico. Em oposição a isso, Bourdieu defendia que a escolha do método de pesquisa deve estar integralmente submetida à natureza do objeto a ser investigado e fazia questão de deixar claro que um modelo teórico não precisa se revestir de forma matemática para ser rigoroso.

Na Ciência Política, esta discussão é bastante intensa devido ao forte compromisso deste campo com a questão da causalidade. Há relativo consenso na literatura sobre a capacidade dos métodos quantitativos e da análise estatística de produzir inferências causais. Por outro lado, ainda existe ampla reflexão sobre essa mesma capacidade para os métodos qualitativos. (REZENDE, 2011)

Ainda na década de 1990, King, Keohane e Verba (1994) publicaram uma das obras mais emblemáticas no campo metodológico da Ciência Política. De tão famosa que é, possui até jargão próprio para designá-la: $K K V^{7}$. Os autores estavam especialmente preocupados com a "falta de rigidez" das pesquisas qualitativas, principalmente no que se refere às possibilidades de produzir inferências causais e consideravam particularmente graves dois limites: o viés de seleção e o problema da generalização.

Os autores argumentam que pesquisadores não podem dizer muita coisa sobre causalidade sem levar em conta diversos valores de uma variável. Por isso, o estudo de um ou poucos $\operatorname{casos}^{8}$ levaria a pesquisa qualitativa a ter baixa capacidade de fazer inferências causais, principalmente quando a seleção desses casos envolve escolhas do próprio pesquisador. Em oposição a isso, seria necessário estudar uma amostra com muitos casos, de

\footnotetext{
${ }^{7}$ A sigla faz referência aos sobrenomes dos autores: King, Keohabe e Verba (1994).

8 Quando uma pesquisa apresenta um ou poucos casos, frequentemente é utilizado o jargão small-n para caracterizá-la em oposição ao big-n, que é a pesquisa cuja amostra tem muitos casos, geralmente com aplicações estatísticas. Não se pode deixar de notar a hegemonia que a linguagem estatística exerce no campo científico, capaz de ser utilizada para caracterizar até aquilo que está fora do seu alcance.
} 
preferência aleatórios, para que fosse possível observar a variabilidade e fazer inferências causais confiáveis, sem viés de seleção e com maior potencial de generalização. (REZENDE, 2011)

O KKV faz então uma proposta integrativa entre métodos quantitativos e qualitativos: para que a tradição qualitativa passasse a produzir resultados inferenciais mais confiáveis, bastaria que seus desenhos de pesquisa fossem orientados pelas mesmas regras que regem as pesquisas quantitativas. Essa é uma proposta integrativa com viés quantitativista, pois defende que toda pesquisa, qualitativa ou quantitativa, deveria ser regida pela lógica quantitativa (REZENDE, 2011), o que atraiu uma série de críticas formuladas por pesquisadores vinculados aos métodos qualitativos. Uma das críticas mais atuais é a de Mahoney (2010), que teorizou sobre uma "nova metodologia qualitativa" argumentando que existem traços distintivos essenciais nos desenhos de pesquisa qualitativos que são intratáveis se forem abordados por uma lógica quantitativista de inferência causal.

Bastante alinhada ao pensamento metodológico de Bourdieu, a linha argumentativa de Mahoney (2010) apresenta três condições específicas em que os métodos quantitativos se tornam inadequados para produzir inferências causais na Ciência Política (REZENDE, 2011). A primeira reside na divergência entre desenhos de pesquisa quantitativos e qualitativos no que se refere à relação entre causas e efeitos. A análise estatística está geralmente voltada para entender os "efeitos das causas", e para isso se vale de métodos de regressão para o teste de hipóteses, por exemplo.

Entretanto, há pesquisas mais interessadas em entender as "causas dos efeitos", um tipo de desenho para o qual os métodos quantitativos se tornam inadequados. Pesquisadores dessa linha se interessam em compreender mais de perto como um determinado efeito foi causado, a partir da suposição de que a causalidade é afetada por condições específicas envolvidas em certas situações cuja devida compreensão exige métodos qualitativos que estudem intensamente uma amostra pequena. (REZENDE, 2011)

A segunda condição diz respeito à singularidade dos fenômenos políticos. As pesquisas quantitativas geralmente estão voltadas a estabelecer hipóteses de causalidade generalizáveis a partir da observação de regularidades. Entretanto, muitos fenômenos políticos são raros, únicos, e pouco tem a ver com análise de padrões. Enquanto no estudo de fenômenos regulares pode haver uma forte preocupação com viés de seleção e capacidade de generalização, no estudo de fenômenos raros ou únicos essas preocupações perdem força. Não faz sentido falar em viés de seleção ao se selecionar, por exemplo, o caso da Revolução Francesa para se estudar a Revolução Francesa. O caso é único. Tampouco faz sentido estudar 
a Revolução Francesa com o objetivo de fazer generalizações sobre outras revoluções francesas. A natureza da explicação é única, aplicável apenas àquele fenômeno. Essa condição é essencial para a escolha do método mais adequado. Em pesquisas sobre fenômenos políticos raros ou únicos, é mais adequada a escolha por métodos qualitativos. (REZENDE, 2011)

Por fim, a terceira condição reside na relevância que elementos agênticos e institucionais possuem nos mecanismos explicativos de certas pesquisas. Análises que levam em conta esses elementos geralmente privilegiam contextos, contingências, escolhas, interações e outros fatores que são mais bem capturados por desenhos de pesquisa qualitativos. Para pesquisas dessa natureza, é mais adequada a escolha por métodos qualitativos. (REZENDE, 2011)

O reconhecimento dessas condições permite que as escolhas metodológicas feitas pelos pesquisadores não aconteçam apenas a partir de preferências particulares, mas sim com base em critérios essencialmente metodológicos (REZENDE, 2011). No caso desta pesquisa, consideramos presentes as três condições indicadas por Mahoney.

Primeiramente, o desenho da pesquisa está mais preocupado com "as causas dos efeitos" do que com "os efeitos das causas", especialmente no que se refere às causas pelas quais surgiram determinadas interações discursivas, e não outras. Além disso, a questão da singularidade ou raridade de certos fenômenos políticos está presente no objeto pesquisado, dado que os discursos sobre a possibilidade de haver orçamento sigiloso em contratações públicas não se repetem com muita frequência, são raros. Por fim, ao abordar ideias e discursos, o olhar teórico da pesquisa embute agência e instituições nos mecanismos explicativos. Assim, dada a natureza do desenho da pesquisa, a raridade do objeto pesquisado e o tipo de teoria explicativa, consideramos adequada, portanto, a escolha por método qualitativo com amostra pequena.

Evidentemente, essa abordagem inviabiliza conclusões generalizantes, mas isso não se torna um problema porque o trabalho se volta a compreender uma tensão discursiva que ocorreu nas situações especificamente trabalhadas. Dessa forma, conclusões mais gerais sobre a tensão mapeada não podem resultar deste trabalho isoladamente, mas a comparação deste trabalho com outros que abordem objeto similar (especialmente analisando os discursos referentes a outras inovações procedimentais na gestão pública) pode, cumulativamente, contribuir para a construção de um conhecimento transversal mais amplo sobre esse tema, que seja capaz de acoplar as conclusões de uma gama de trabalhos que explorem os discursos políticos sobre a gestão pública. 


\section{O material de pesquisa}

Dois recortes básicos orientaram a busca pelo material de pesquisa. O primeiro deles se refere aos três momentos em que o orçamento sigiloso foi inserido nas regras brasileiras de contratação pública. Esses momentos são: a introdução do orçamento sigiloso no âmbito da Anatel, nos anos 1990, depois, no âmbito do Pregão, no início dos anos 2000, e, por último, no âmbito do RDC, já na década de 2010. O segundo recorte se refere aos grupos de agentes cujos discursos são analisados pela pesquisa: políticos governistas, políticos oposicionistas e agentes de órgãos de controle. A combinação dos três momentos com os três grupos de agentes resultaria em uma matriz de ordem $3 \times 3$, com nove lacunas a serem preenchidas com o discurso de cada grupo referente a cada momento em que o orçamento sigiloso apareceu nas regras.

Esta busca inicial revelou dois achados relevantes. O primeiro deles é que nem sempre o orçamento sigiloso foi tema específico de discussão entre esses agentes. No momento Anatel, houve intensa interação discursiva sobre as mudanças institucionais, mas ninguém discutiu abertamente sobre o orçamento sigiloso. No momento Pregão, pelo menos os agentes de órgãos de controle já trataram especificamente sobre o assunto. Já no momento RDC, o orçamento sigiloso foi discutido pelos três grupos de agentes. O outro achado é que os padrões de interação discursiva encontrados em cada momento são diferentes. No momento Anatel e no momento RDC, houve intenso debate no Supremo Tribunal Federal (STF). Já no momento Pregão, o debate foi mais forte no Tribunal de Contas da União (TCU).

Essa ausência de debate constitui um silêncio argumentativo relevante, de tal forma que essa ausência se tornou um dos fenômenos a serem investigados pela pesquisa. Isso significa que a matriz de discursos que cruza os três momentos com os três grupos de agentes (Tabela 02) é assimétrica em relação a esses dois fatores. Ou seja, será admitido que as interações entre determinados grupos em um momento se dão de forma estritamente diferente das interações entre os mesmos grupos em outro momento. Além disso, será admitido que alguns discursos tratem especificamente do orçamento sigiloso, outros não, embora todos tratem de mudanças institucionais relacionadas ao orçamento sigiloso. 
Tabela 01 - Esquema do material de pesquisa utilizado

\begin{tabular}{|c|c|c|c|}
\hline & Políticos governistas & Políticos oposicionistas & Órgãos de controle \\
\hline $\begin{array}{c}\text { Momento } \\
\text { Anatel } \\
\text { (A partir de 1997) }\end{array}$ & $\begin{array}{l}\text { - Exposição de Motivos } \mathrm{n}^{\circ} \\
\text { 231/1996 do MC }\end{array}$ & $\begin{array}{l}\text { - Petição inicial da ADI } n^{\circ} \\
1.668\end{array}$ & $\begin{array}{l}\text { - Votos do acórdão da ADI } \\
\text { no } 1.668\end{array}$ \\
\hline $\begin{array}{c}\text { Momento } \\
\text { Pregão } \\
\text { (A partir de 2000) }\end{array}$ & $\begin{array}{l}\text { - Exposição de Motivos } \mathrm{n}^{\circ} \\
\text { 93/2000 do MPOG }\end{array}$ & $\begin{array}{l}\text { - Propostas de emenda } \\
\text { parlamentar à MPV do } \\
\text { Pregão }\end{array}$ & $\begin{array}{l}\text { Acórdãos TCU - Plenário } \\
\text { - no } 254 / 2004 \\
\text { - no } 201 / 2006 \\
\text { - no } 664 / 2006 \\
\text { - no } 1.925 / 2006 \\
\text { - no } 410 / 2006 \\
\text { - no } 1.405 / 2006 \\
\text { - no } 114 / 2007\end{array}$ \\
\hline $\begin{array}{c}\text { Momento } \\
\text { RDC } \\
\text { (A partir de 2011) }\end{array}$ & $\begin{array}{l}\text { - Parecer } \mathrm{n}^{\circ} 2.903 / 2011 \mathrm{da} \\
\mathrm{SAJ} / \mathrm{CC} \\
\text { - Prestação de Informações } \mathrm{n}^{\circ} \\
113 / 2011 \mathrm{da} \text { AGU }\end{array}$ & $\begin{array}{l}\text { - Petição inicial da ADI } n^{\circ} \\
4.645\end{array}$ & $\begin{array}{l}\text { Acórdãos TCU - Plenário } \\
\text { - no } 3.011 / 2012 \\
\text { - no } 3.366 / 2012 \\
\text { - no } 306 / 2013\end{array}$ \\
\hline
\end{tabular}

No momento Anatel, o orçamento sigiloso surgiu com a Lei Geral de Telecomunicações (LGT). Neste momento analisaremos três discursos. O primeiro se refere ao discurso dos políticos governistas para justificar a LGT extraído da Exposição de Motivos $n^{\circ}$ 231/1996 do Ministério das Comunicações (MC). O segundo discurso trata das ideias utilizadas por políticos oposicionistas para tentar derrubar a LGT no STF, extraído da petição inicial da Ação Direta de Inconstitucionalidade (ADI) $n^{\circ}$ 1.668. Por fim, o terceiro discurso trata de resposta dos ministros do STF ao pedido dos políticos oposicionistas, extraído dos votos do acórdão da ADI nº 1.668 .

No momento Pregão, o orçamento sigiloso apareceu já na primeira Medida Provisória a tramitar sobre o assunto, tendo prevalecido até a conversão em lei. Neste momento também serão examinados três discursos. O primeiro deles se refere ao discurso dos políticos governistas para defender a nova modalidade de licitação, extraído da Exposição de Motivos no 93/2000, do Ministério do Planejamento, Orçamento e Gestão (MPOG). Para captar a reação dos políticos oposicionistas, analisaremos as propostas de emenda que a matéria recebeu. Por fim, o discurso do Tribunal de Contas da União (TCU) sobre o orçamento 
sigiloso no âmbito do Pregão será analisado a partir de acórdãos referentes aos quatro casos concretos onde o uso do orçamento sigiloso foi questionado.

Finalmente, no momento RDC o orçamento sigiloso surgiu na aprovação da lei do novo regime. O primeiro discurso tratará das ideias utilizadas por políticos oposicionistas para tentar derrubar o RDC, extraído da petição inicial da ADI n 4.645. O segundo discurso se refere às ideias empregadas por políticos governistas para defender as inovações do RDC, extraído do Parecer no 2.903/2011 da Subchefia de Assuntos Jurídicos (SAJ) da Casa Civil (CC) e da Prestação de Informações nº 113/2011 da Advocacia-Geral da União (AGU). Por fim, as ideias do TCU sobre questões práticas direcionadas ao orçamento sigiloso serão captadas a partir de trechos de acórdãos onde o Tribunal se manifesta sobre o assunto.

\section{O tratamento dos dados}

Conforme será esclarecido de forma mais adequada no Capítulo 2, a perspectiva teórica que orienta a abordagem desta pesquisa é o Institucionalismo Discursivo, que combina elementos institucionais e agênticos ao empregar explicações que consideram não só as ideias presentes em um determinado discurso (dimensão representativa), mas também a maneira como essas ideias são veiculadas (dimensão interativa). A dimensão representativa dos discursos será tratada na Parte II, onde descreveremos as ideias encontradas nos discursos, organizando-as nas categorias propostas por Schmidt (2008): filosofias, programas e políticas. Já a dimensão interativa será analisada na Parte III, onde mostraremos como essas ideias foram colocadas em movimento pelos agentes em seus discursos.

Para cada discurso extraído do material de pesquisa será elaborada uma ficha, cujo modelo está detalhado na Tabela 02. A finalidade é representar os discursos encontrados de maneira mais analítica. As categorias presentes nessa ficha derivam diretamente da perspectiva teórica do ID, que busca entender não só as ideias por trás de algo que é dito, mas por quem, para quem, onde, como, quando e por que algo é dito. Schmidt (2008) adota uma classificação de discursos que os diferencia entre comunicativos e coordenativos. No âmbito dessa pesquisa, todos os discursos analisados foram do tipo coordenativo, ou seja, são propagados por e para agentes estatais, de modo que esta classificação não será utilizada na pesquisa. 
Tabela 02 - Modelo de ficha analítica de discurso

\begin{tabular}{|r|l|}
\hline Código & Corresponde a uma numeração simples para identificar cada discurso \\
\hline Quem? & Corresponde ao agente que propagou o discurso \\
\hline Para quem? & Corresponde aos destinatários do discurso propagado \\
\hline Onde? & Corresponde ao ambiente institucional onde o discurso foi propagado \\
\hline Como? & Corresponde à forma como o discurso foi propagado \\
\hline Quando? & Corresponde ao momento em que o discurso foi propagado \\
\hline Por que? & Corresponde à razão pela qual o discurso foi propagado \\
\hline Caráter geral & Corresponde às ideias encontradas no discurso propagado. \\
do discurso & anti-corrupção ou pró-eficiência. \\
\hline
\end{tabular}

A parte II, enquanto representação de ideias, terá um caráter mais institucionalista. Já a parte III, enquanto dinâmica interativa dos discursos, terá um caráter mais agêntico. A escolha por tratar a dimensão representativa e a dimensão interativa dos discursos em partes diferentes do texto se deu no intuito de favorecer a fluidez do relato da dimensão interativa, já que não será necessário interromper o relato para explicar e classificar cada ideia nova que surge no discurso dos agentes. No entanto, reforçamos que as ideias descritas na parte II são derivadas diretamente dos discursos apresentados na parte III. 


\section{Capítulo 2: $O$ institucionalismo discursivo}

Toda teoria tem seus pontos cegos e comporta distorções impostas pela perspectiva de análise que ela adota. No caso dos institucionalismos, o enfoque no modo como as instituições condicionam as relações políticas faz com que as teorias busquem explicar a sociedade em função dos arranjos institucionais existentes, o que deixa um espaço reduzido para questionamentos acerca do surgimento e do desenvolvimento das próprias instituições. Quando se busca explicar a ação individual em termos de observância de regras institucionais, as instituições são tomadas como fatos quase naturais, o que minimiza os debates acerca de como elas são criadas e modificadas pelas pessoas.

Se indivíduos conseguem pensar e agir fora das condicionantes institucionais, porque as instituições continuam "estáveis"? Interesses, preferências, normas culturais e regularidades históricas são aspectos materiais das instituições? Construtos sociais podem produzir efeitos reais? Como a psicologia humana condiciona as instituições políticas?

É possível multiplicar essas perguntas indefinidamente, o que indica que a realidade política é complexa e nenhuma abordagem metodológica é suficiente para explicar todos os elementos de análise. Toda teoria precisa simplificar a realidade para evidenciar padrões factuais ou normativos, e essa redução da complexidade não precisa ser vista como falha, mas como parte da própria estratégia cognitiva envolvida na formulação de explicações abrangentes baseadas em uma observação cuidadosa do mundo.

Considerando que cada perspectiva teórica acentua a relevância de alguns elementos para formular explicações, a opção por um determinado marco teórico não decorre de sua verdade intrínseca, mas de sua capacidade de organizar adequadamente as narrativas acerca de um determinado objeto. No caso das teorias políticas, sua utilidade deve ser avaliada em função do quanto ela pode contribuir para aprimorar nossas percepções sobre a realidade social, seja corrigindo distorções ou ampliando a abrangência dos modos de compreensão disponíveis.

O marco teórico do Institucionalismo Discursivo (ID) foi escolhido para organizar esta pesquisa por duas razões principais. Conforme será explicado a seguir, a teoria trata elementos institucionais e agênticos de forma complementar, de modo que as instituições são consideradas simultaneamente como estruturas e construtos, moldando o comportamento dos agentes ao mesmo tempo em que é moldada por esses comportamentos. Além disso, o ID aborda instituições e agência por meio de noções como ideias e discursos, categorias analíticas bastante aderentes aos propósitos da pesquisa. 


\section{O debate entre agência e instituições}

O chamado neo-institucionalismo surgiu na década de 1980 em resposta a uma ênfase excessiva em agência sem estrutura, a exemplo do individualismo metodológico do behaviorismo (SCHMIDT, 2008). Ao adotar o comportamento individual como unidade de análise, o behaviorismo tratou os fenômenos sociais como agregados de escolhas individuais, perspectiva que foi inovadora em meados do século $\mathrm{XX}$, mas que logo se mostrou pouco capaz de explicar devidamente os fenômenos sociais a partir de suas causas ou de lidar com interações complexas, em que os comportamentos se condicionam mutuamente. (PERES, 2008).

A adoção de um marco institucionalista prometia superar esses limites porque se concentrava em fenômenos propriamente sociais (os padrões comportamentais organizados em formas de instituições), favorecendo o desenvolvimento de um discurso sobre estruturas que permitiam identificar padrões de organização social. Todavia, um enfoque demasiado no modo como as instituições determinam a ação individual tornava o institucionalismo pouco capaz de explicar as relações entre agência e estrutura.

Diferentes concepções ligadas ao movimento neo-institucionalista adotaram definições diversas de instituição, a depender do tipo de estrutura social que se adotava como unidade de análise, e a partir do trabalho de Hall e Taylor (1996) tornou-se comum a agregação dessas teorias em três grandes vertentes: Institucionalismo da Escolha Racional (IR), que define as instituições como estruturas de incentivos às quais os agentes se ajustam na tentativa de maximizar seus interesses; o Institucionalismo Histórico (IH), que entende as instituições como trajetórias históricas que, na medida em que vão sendo ratificadas, aumentam o "custo" de escolher outro caminho e o Institucionalismo Sociológico (IS), que trata as instituições como normas culturais cuja reprodução as torna cada vez mais fortes.

Essas três correntes tendem a explicar as relações entre as estruturas e os indivíduos de forma unilateral: elas funcionam de forma externa aos agentes, condicionando e restringindo a ação. Segundo Vivien Schmidt (2008), os institucionalismos tradicionais entendem os agentes como seguidores de regras, seja em uma lógica de cálculo baseado em interesses (IR), em uma lógica de dependência de trajetória baseada em aspectos históricos (IH) ou em uma lógica de reprodução baseada em normas culturais (IS).

A questão que emerge dessa constatação é: se todos os agentes são meros seguidores de regras, quem cria as instituições que definem as regras? E quem pode mudar as instituições e, consequentemente, as regras? Estas são algumas das questões centrais que explicitam as 
limitações das três vertentes do neo-institucionalismo, e que motivam muitos teóricos a buscar perspectivas que articulem melhor os conceitos de agência e instituição.

Anthony Giddens (2000), por exemplo, insistiu por décadas que a estrutura deve ser considerada como dual, pois ela influencia os comportamentos ao mesmo tempo em que é permanentemente constituída e modificada por eles. Ideia semelhante já era desenvolvida por Pierre Bourdieu (1983), que, ao esboçar a sua teoria da prática, considerava que estruturas e comportamentos se atualizam mutuamente em um duplo processo de interiorização da exterioridade e de exteriorização da interioridade.

Essa ideia de que há uma interação constante entre agência e estrutura continua estimulando o debate atual, como na teoria das instituições habitadas, de Hallet e Ventresca (2006), que consideram que as instituições fornecem material bruto para as interações sociais ao mesmo tempo em que os significados das instituições são construídos pelas interações sociais, e na teoria do trabalho institucional de Lawrence, Suddaby e Leca (2009), que acentua os pequenos ajustes, adaptações e engajamentos propositais no dia a dia dos agentes, que constantemente buscam modificar ou manter as suas instituições. Outros pesquisadores, em vez de acentuar que as instituições são constituídas por uma combinação de microrelações, buscam identificar agentes com especial influência, como Adam Sheingate (2003), que acentuou o fato de que certos atores relativamente poderosos, os quais ele chama de empreendedores políticos, têm capacidade especial de transformar as instituições.

A noção de que a interferência das instituições sobre os atores se dá na qualidade de guia, restrição ou roteiro também tem sido questionada por concepções como a teoria da criatividade política, de Berk, Galvan e Hattam (2013), que consideram que a instituição informa a ação na qualidade de material bruto para improvisação e transformação. Outro ponto relevante de crítica sobre as formas de interação entre atores e estruturas retoma uma questão que já havia sido levantada pelo pragmatismo de John Dewey, para quem cada ação humana, por menor que seja, é uma experiência nova e única, e não uma reprodução do passado (JOAS, 1996). Em sentido semelhante, Emirbayer e Mische (1998) acentuam que os agentes estão sempre considerando o passado, o presente e o futuro, ajustando estas temporalidades umas às outras. Isso significa que os agentes estão simultaneamente sendo influenciados por padrões do passado, adaptando as suas ações às emergências do presente e projetando caminhos hipotéticos para o futuro.

Essa multiplicidade de teorias indica que há uma literatura emergente, da qual o ID faz parte, que tem como característica central uma ressignificação das categorias de agência e 
instituições e um questionamento sobre os modos adequados de descrever as interações sociais a partir dessas dimensões.

\section{O Institucionalismo Discursivo}

Este marco teórico se relaciona com uma recente valorização de processos ideacionais no âmbito da Ciência Política, fenômeno que aconteceu a partir de perspectivas relativamente diferentes, como na virada ideacional (BLYTH, 1997), no institucionalismo discursivo (CAMPBELL e PEDERSEN, 2001), no institucionalismo construtivista (HAY, 2006) e no construtivismo estratégico (JABKO, 2006). Vivien Schmidt articulou essas perspectivas em uma abordagem teórica consideravelmente ampla, à qual chamou de Institucionalismo Discursivo (ID). Para ela, institucionalistas discursivos são aqueles que levam ideias e discursos a sério em seus estudos; dinamizando os conceitos de instituições, agência, interesses, regularidades e normas; o que significa desafiar as premissas básicas das três correntes do neo-institucionalismo (SCHMIDT, 2008).

É importante notar que o desafio é tanto ontológico (o que são instituições e como elas são criadas, mantidas ou alteradas) quanto epistemológico (o que podemos saber sobre instituições e sobre o que as faz mudar ou persistir). No ID, as instituições são definidas simultaneamente como estruturas e construtos, estruturando a ação dos agentes ao mesmo tempo em que são continuamente (re)constituídas pela ação deles (SCHMIDT, 2008). A agência, por sua vez, está situada no que Schmidt chama de habilidades ideacionais de fundo (background ideational abilities) e habilidades discursivas de primeiro plano (foreground discursive abilities). Por meio de habilidades ideacionais, os agentes reagem a ideias subjetivas sobre aspectos institucionais, sendo a ação estruturada a partir de ideias prévias sobre interesses e preferências, sobre como interpretar regularidades históricas, ou sobre os sentidos de uma norma cultural. Por outro lado, as habilidades discursivas permitem que os agentes pensem, falem e ajam por fora da lógica das suas instituições, ainda que eles permaneçam ligados a elas; deliberem sobre regras institucionais, ainda que eles as sigam; e convença outros agentes a mudar ou manter essas instituições. (SCHMIDT, 2008)

A combinação entre habilidades ideacionais e discursivas coloca a agência de volta à análise institucional. As instituições e os agentes parecem estar conectados por ideias sobre como agir a partir das regras, de modo que os discursos são as forças que movimentam e ressignificam estas ideias, tendo o poder de alterar, portanto, as relações entre as instituições e os agentes. Segundo Schmidt e Radaelli (2004), o ID é amplo o suficiente para abranger a 
maioria das abordagens que utilizam ideias e discursos. Este pluralismo se refere tanto ao grau de materialismo das abordagens quanto à vertente neo-institucionalista adotada.

Em termos de materialismo, apesar dos fundamentos do ID apontarem para concepções mais construtivistas, Schmidt e Radaelli (2004) afirmam que ele é compatível com abordagens tanto positivistas (ideias vistas como reflexos de interesses e disposições materiais), quanto construtivistas (ideias vistas como constituidoras de interesses e disposições). Em favor dos positivistas, Schmidt e Radaelli (2004) argumentam que, embora a realidade possa ser discursivamente construída, isso não implica que a análise deve ser limitada ao discurso, de modo que condições ditas materiais também ajudam nas explicações. Já em favor dos construtivistas, Schmidt e Radaelli (2004) argumentam que, ainda que as ideias que constituem interesses e disposições possam ser subjetivas ou imateriais, isso não significa que elas não existam ou que não produzam efeitos bastante reais. Instituições podem ser reais no sentido de que elas constituem interesses e disposições, fazendo coisas acontecerem, mesmo que elas sejam socialmente construídas, e não materiais. Assim, concluem que pode ser mais útil identificar o que é real, mesmo que não seja material.

Já em relação à compatibilidade do ID com as três vertentes do neo-institucionalismo, Schmidt (2008) defende que as abordagens sejam vistas como complementares. Instituições, entendidas como estruturas baseadas em incentivos, regularidades históricas ou normas culturais, enquadram o discurso. Elas definem os contextos institucionais dentro dos quais ideias e discursos são mais ou menos aceitáveis. Mas Schmidt (2008) defende que além da simples consideração de categorias como ideias e discursos, é preciso romper com as premissas básicas das três vertentes clássicas.

Em relação ao IR, o uso das ideias ajuda a resolver problemas que não podiam ser tratados exclusivamente em termos de interesses, como a questão de como as preferências são criadas e como elas podem ser alteradas. No IH, o uso das ideias ajuda a abordar as rupturas de trajetória como objetos explicativos, e não mais como momentos críticos inexplicáveis. E no IS, abordagem já velha conhecida das ideias e dos discursos, a diferença reside mais no grau em que as instituições são tratadas como estruturas e construtos simultaneamente, e não somente como estruturas estáticas.

Entretanto, o discurso, como qualquer outro fator, às vezes importa para uma determinada explicação, às vezes não. A questão é quando o discurso importa, por exemplo, redefinindo interesses ao invés de refleti-los, reinterpretando rupturas históricas ao invés de tratá-las como momentos críticos ou ressignificando regras ao invés de reproduzi-las. Além disso, o IR, o IH e o IS fornecem conhecimento valioso sobre o que normalmente esperar em 
um contexto, dadas as restrições estruturais, em oposição a eventuais resultados inesperados, os quais talvez possam ser explicados por meio de ideias e discursos.

\section{O poder das ideias}

As abordagens mais positivistas tendem a considerar ideias como a representação das condições materiais para a ação coletiva, servindo, por exemplo, para refletir interesses econômicos ou para configurar coalisões políticas baseadas em interesses. Já as abordagens mais construtivistas tendem a conceber as ideias como constituidoras das narrativas, discursos e enquadramentos, servindo, por exemplo, para reconstruir a compreensão dos agentes sobre interesses e redirecionar suas ações dentro das instituições. Para outros, ainda, ideias refletem as identidades nacionais, valores, normas e memórias coletivas que moldam compreensões sobre preferências, regularidades e normas (SCHMIDT e RADAELLI, 2004).

Há, portanto, muitas ideias sobre ideias. Ideias podem assumir a forma de mapas cognitivos, construções estratégicas, narrativas, memórias coletivas ou tradições nacionais, dentre muitas outras. Schmidt (2008) propõe uma plataforma para mapear e organizar ideias baseada no nível de generalidade e no tipo de conteúdo (Tabela 03). Em relação ao nível de generalidade, as ideias podem ser políticas (policies), programas $^{9}$ ou filosofias. Já em relação ao tipo de conteúdo, as ideias variam entre cognitivas e normativas.

\footnotetext{
9 No jargão da administração pública brasileira, o termo programa geralmente é usado em sentido mais específico que o termo política. No entanto, é importante esclarecer que na classificação de Schmidt, programas se referem a ideias mais abrangentes que políticas.
} 
Tabela 03 - Tipos de ideia segundo grau de generalidade e conteúdo

\begin{tabular}{|c|c|c|c|}
\hline \multicolumn{4}{|c|}{ IDEIAS SEGUNDO O GRAU DE GENERALIDADE } \\
\hline Filosofias & \multicolumn{2}{|c|}{ Programas } & Políticas \\
\hline $\begin{array}{l}\text { São visões de mundo, } \\
\text { sentimentos públicos, filosofias } \\
\text { públicas. Sustentam as políticas } \\
\text { e programas com valores e } \\
\text { princípios que organizam o } \\
\text { conhecimento e a sociedade. }\end{array}$ & \multicolumn{2}{|c|}{$\begin{array}{l}\text { Definem problemas a serem } \\
\text { resolvidos; questões a serem } \\
\text { consideradas; metas a serem } \\
\text { alcançadas; normas, métodos e } \\
\text { instrumentos a serem aplicados. }\end{array}$} & $\begin{array}{l}\text { São medidas específicas e mais } \\
\text { imediatas propostas para } \\
\text { resolver um dado problema. }\end{array}$ \\
\hline \multicolumn{4}{|c|}{ IDEIAS SEGUNDO O TIPO DE CONTEÚDO } \\
\hline \multicolumn{2}{|l|}{ Cognitivas } & & Normativas \\
\hline \multicolumn{2}{|c|}{$\begin{array}{l}\text { Dizem respeito a como determinada política pode } \\
\text { resolver um dado problema, a como uma dada } \\
\text { questão é um problema e a como políticas e } \\
\text { programas estão alinhados a princípios e normas } \\
\text { tecnicamente e cientificamente relevantes. Em } \\
\text { outras palavras, as ideias cognitivas buscam trazer } \\
\text { credibilidade técnica e científica para a ação, } \\
\text { sugerindo porque algo pode ser feito. }\end{array}$} & \multicolumn{2}{|c|}{$\begin{array}{l}\text { Referem-se a como as políticas atendem às } \\
\text { aspirações e ideias das pessoas em geral, } \\
\text { ressonando um grau mais profundo de princípios e } \\
\text { normas da vida pública. Em outras palavras, as } \\
\text { ideias normativas buscam trazer legitimidade } \\
\text { política para a ação, indicando porque algo deve } \\
\text { ser feito. }\end{array}$} \\
\hline
\end{tabular}

Elaboração própria. Fonte: Schmidt (2008).

O poder das ideias parece residir no fato de que, uma vez que uma ideia se torna dominante, ela passa a influenciar a ação dos agentes. Portanto, uma grande questão para pesquisadores focados em ideias é o porquê de certas ideias se tornarem as políticas, programas e filosofias que dominam a vida social e política, e não outras. Há muitas linhas de pesquisa buscando responder esta questão a partir dos diferentes níveis de generalidade das ideias. Em relação às políticas e aos programas, por exemplo, existe uma vasta literatura sobre políticas públicas, que busca compreender quais são os fatores determinantes na formulação de políticas. Já a identificação e crítica às filosofias públicas tem sido o domínio de macro sociólogos; como Max Weber, Pierre Bourdieu, Michel Foucault e Antonio Gramsci (SCHMIDT, 2008).

Por mais que esses estudos ajudem a identificar os fatores necessários para o sucesso de certas ideias, às vezes estas abordagens tratam o conjunto de ideias dominantes como dado, pré-estabelecido, isto é, de forma razoavelmente estruturalista. Se a análise for limitada a isso, não há como entender os processos pelos quais tais ideias saíram da cabeça de alguém para o “papel”, e do "papel” para a realidade. (SCHMIDT, 2008) 
Considerando que a habilidade ideacional dos agentes ajuda a explicar certos comportamentos a partir de ideias sobre interesses, regularidades ou normas, o ID busca integrar esses elementos e explicar como tais ideias podem ser formadas ou alteradas, o que levanta a questão da habilidade discursiva dos agentes.

\section{A dinâmica do discurso}

O conceito de discurso é mais versátil e abrangente que o conceito de ideia. Ao usar o termo discurso, podemos simultaneamente indicar as ideias representadas no discurso (que podem conter diferentes formas e conteúdos, conforme já discutido) e os processos interativos pelos quais as ideias são transmitidas (que podem envolver diferentes agentes em diferentes esferas) (SCHMIDT, 2008). Discursos são definidos tanto em termos de seu conteúdo quanto em relação aos seus processos interativos. A dimensão representativa se refere às ideias nele representadas, ou seja, o que é transmitido. Já a dimensão interativa trata de como ele é veiculado, ou seja, por quem, para quem, quando, por que, onde e como as ideias são transmitidas. (SCHMIDT, 2008)

Enquanto representação, o discurso articula diferentes níveis de ideias (políticas, programas e filosofias) com diferentes tipos de conteúdo (ideias cognitivas e normativas) e em formas variadas (narrativas, enquadramentos, memórias coletivas, histórias, cenários, imagens, dentre muitas outras possibilidades) (SCHMIDT, 2008). Já enquanto processo interativo, o discurso coloca estas ideias em movimento, direcionando diferentes combinações de forma e conteúdo para pessoas diferentes, em momentos diferentes por razões diferentes, o que ajuda a explicar o porquê de certas ideias vencerem e outras falharem (SCHMIDT, 2008). Conforme já foi mencionado, esta pesquisa enfatizará estas duas dimensões discursivas: o conjunto de ideias embutidas no discurso e o processo interativo pelo qual o discurso foi veiculado.

Schmidt (2008) trabalha com dois tipos principais de esferas onde os discursos são veiculados. A esfera coordenativa é habitada por indivíduos envolvidos na criação, elaboração e justificativa de ideias políticas e programáticas. Essa esfera é muitas vezes referenciada na literatura como comunidades epistêmicas, coalisões de defesa, coalisões discursivas, redes de defesa, empreendedores políticos, dentre outros. Já a esfera comunicativa consiste na apresentação, deliberação e legitimação de ideias em relação ao público geral. Além da densa propagação de discursos comunicativos em processos eleitorais, esta esfera também envolve esforços persuasivos direcionados a grupos mais organizados, como partidos de oposição, 
grande mídia, intelectuais, movimentos sociais e o próprio mercado, dentre outros. (SCHMIDT, 2008)

É importante notar que para Schmidt (2008), embora os discursos pareçam fluir naturalmente da esfera coordenativa (elites formulando ideias) para a esfera comunicativa (elites tentando legitimar ideias), isso nem sempre acontece. A direção do fluxo pode ser da esfera comunicativa para a coordenativa, por exemplo, por meio das interações discursivas de ativistas sociais que tentam influenciar na formulação de políticas. Também pode acontecer de não haver conexão alguma entre os discursos coordenativos e comunicativos, por exemplo, quando os debates sobre ideias coordenativas ficam restritos a altos gabinetes, seja porque tratam de ideias impopulares demais ou porque são questões muito técnicas para atrair o interesse das pessoas.

Enfim, no âmbito do ID, o discurso é um conceito mais amplo que abrange tanto o conteúdo substantivo das ideias quanto os processos interativos pelos quais elas são veiculadas. O termo se refere não só à instituição (o que é dito, onde e como), mas também à agência (quem disse o que para quem e por que).

\section{Discursos e instituições}

O discurso não deve ser examinado isoladamente. É necessário compreendê-lo à luz do contexto institucional, daí o termo "institucionalismo discursivo". Isso significa que o discurso deve ser considerado tanto a partir de outros fatores que afetam a instituição, mas também em termos das regras que enquadram ideias e discursos em uma determinada configuração. O contexto institucional é permeado por normas e convenções, formais e informais, que configuram um quadro de referência comum, moldando não só os interesses e disposições dos agentes, mas também as suas formas de interagir. Esses arranjos ajudam a parametrizar o que as pessoas falam e com quem falam no decorrer dos processos discursivos. (SCHMIDT e RADAELLI, 2004)

Por exemplo, em países onde o poder é mais concentrado no poder executivo, a formulação de políticas é mais restrita a uma elite governamental, e esse contexto institucional é mais propenso a se dedicar a discursos comunicativos sofisticados para persuadir o público em geral sobe a necessidade e legitimidade das políticas defendidas pelo governo. Por outro lado, em países onde o poder é mais disperso, como nas democracias federalistas, é mais comum encontrar elaborados discursos coordenativos, já que é preciso 
convencer não só o público em geral, mas também outros grupos importantes, sobre a necessidade e legitimidade de certas políticas. (SCHMIDT, 2008)

Discursos sempre existem, no sentido de que são representação e veiculação de ideias. Entretanto, nem sempre exercem influência causal. O que faz um discurso influenciar a continuidade ou a mudança institucional? Qual é o critério para o sucesso do discurso? A princípio, a dimensão representativa do discurso ajuda a explicar o porquê de um discurso ganhar aceitação ou não. A narrativa discursiva precisa contar uma boa história. As ações que o discurso recomenda devem aparentar factíveis, as soluções devem ser compreensíveis e os resultados esperados devem estar alinhados a princípios e valores mais profundamente enraizados na sociedade. Mas, há casos em que consistência e coerência demais podem levar a uma armadilha retórica, o que significa que os agentes podem ficar confinados aos limites dos seus próprios discursos. Assim, além de credibilidade e legitimidade, é possível que o discurso também se beneficie de certo grau de abstração ou de ambiguidade, de modo que todos esses são critérios que importam para a determinação da influência causal do discurso (SCHMIDT, 2008). Por outro lado, parte da explicação do sucesso de um discurso pode estar na sua dimensão interativa. Discursos tendem a ser mais bem-sucedidos quando os agentes os direcionam às pessoas certas, nos momentos apropriados e de maneiras adequadas. Assim, não só o que é dito, mas quem diz, para quem é dito, quando é dito e como é dito também importa na determinação da influência causal do discurso. (SCHMIDT, 2008) 


\section{PARTE II - AS IDEIAS}

Para Schmidt (2008), as instituições e os agentes parecem estar conectados por ideias sobre como agir a partir das regras, de modo que os discursos são as forças que movimentam e ressignificam estas ideias, tendo o poder de alterar, portanto, as relações entre as instituições e os agentes. De acordo com esta concepção, as ideias têm natureza mais institucional, estruturalista, em oposição aos discursos, que são mais agênticos.

Nesta parte, serão apresentados os aspectos institucionais encontrados nos discursos dos agentes: as ideias. É importante destacar que não está no escopo da pesquisa a construção de uma caracterização detalhada desses aspectos institucionais, mas sim a verificação de como os agentes articulam as ideias em seus discursos. Para esta finalidade, consideramos suficiente mapear e descrever brevemente as ideias encontradas.

Estas ideias serão organizadas a partir das categorias propostas por Schmidt (2008) em relação ao grau de generalidade ${ }^{10}$ (ver Tabela 03). Assim, as ideias anti-corrupção e próeficiência, mais abstratas e estáveis, serão classificadas como filosofias. As ideias relacionadas a cada uma dessas filosofias serão classificadas entre programáticas e políticas, conforme o seu grau de generalidade e estabilidade, conforme a Tabela 04.

Tabela 04 - Esquema das ideias encontradas nos discursos

\begin{tabular}{|l|l|l|}
\hline \multicolumn{1}{|c|}{ Filosofias } & \multicolumn{1}{|c|}{ Programas } & \multicolumn{1}{c|}{ Políticas } \\
\hline Anti-corrupção & $\begin{array}{l}\text { Interesse público } \\
\text { Moralidade } \\
\text { Controle social }\end{array}$ & $\begin{array}{l}\text { Impessoalidade } \\
\text { Isonomia } \\
\text { Rigidez } \\
\text { Publicidade } \\
\text { Transparência }\end{array}$ \\
\hline Pró-eficiência & $\begin{array}{l}\text { Celeridade } \\
\text { Economicidade } \\
\text { Qualidade } \\
\text { Segurança }\end{array}$ & $\begin{array}{l}\text { Flexibilidade } \\
\text { Autonomia } \\
\text { Subjetividade } \\
\text { Inovação } \\
\text { Competitividade } \\
\text { Gestão por resultados }\end{array}$ \\
& & \\
\hline
\end{tabular}

${ }^{10}$ Em relação à classificação por tipo de conteúdo, todas as ideias encontradas podem ser consideradas como normativas, já que trazem fortes elementos ligados à questão da legitimidade. Contudo, esse tipo de classificação parece ser mais útil para pesquisas que buscam analisar tentativas de persuasão e convencimento entre os agentes, por exemplo, não tendo grande utilidade para os fins dessa pesquisa, portanto. 
Em seguida, será apresentada ${ }^{11}$ uma breve noção sobre cada uma dessas ideias, buscando relacioná-las umas com as outras e com a filosofia à qual se associam.

\section{Capítulo 3: A filosofia anti-corrupção}

Esta filosofia e as ideias associadas a ela pareceram dialogar diretamente com uma estrutura ideacional política fundada em imperativos republicanos e democráticos. A sua origem parece estar ligada a processos de regulação do poder político pelo Direito, característica fundamental do Estado Democrático de Direito, o que ajuda a explicar o porquê de predominar nessas ideias a linguagem jurídica.

Segundo Bobbio (1995), a regulação do poder político pelo Direito engloba processos históricos que vão desde a conformação do paradigma do positivismo jurídico até sucessivas adaptações institucionais que tornaram possível a existência em contextos democráticos da onipotência do legislador.

Ainda na Grécia clássica, Aristóteles distinguia direito natural de direito positivo, de modo que o primeiro era aquele que funcionava de um mesmo jeito em toda parte (como o fogo que sempre queima), e o segundo era aquele que estabelecia ações que poderiam funcionar de outra forma caso não fossem assim reguladas (como a necessidade de fazer oferenda de uma ovelha, mas que poderia ser de duas cabras se a lei assim ordenasse). No direito romano, entendia-se por direito natural aquele posto pela natureza e imutável no tempo, enquanto que direito positivo era aquele posto pelo povo e, portanto, mutável. No pensamento medieval o direito natural era aquele posto por alguém que está além dos homens, como Deus, em contraste com o direito positivo, que é posto pelos próprios homens. No pensamento moderno finalmente aparece a figura do Estado nestas distinções. Para Grócio, direito positivo é aquele posto pelo Estado, ou seja, aquele que conhecemos por meio da declaração da vontade do legislador. Filosoficamente, o paradigma do positivismo jurídico surge quando o direito natural passa a não ser mais considerado como direito, de modo que o direito positivo, posto pelo Estado, passa a ser chamado apenas de direito. (BOBBIO, 1995)

Embora neste momento já estivesse caracterizado o Estado legislador, o poder político ainda não estava plenamente regulado pelo Direito. Para chegar a este ponto, duas inovações institucionais foram emblemáticas. A primeira delas foi a separação de poderes, pela qual o

\footnotetext{
11 Importa esclarecer que algumas ideias serão descritas de forma conjunta a partir da afinidade de seus conteúdos, o que em alguns casos significará rompimento com as categorias às quais elas se encontram vinculadas na Tabela 04.
} 
poder de legislar não era mais atribuído ao príncipe, mas a um colegiado, de modo que o governo ficaria submetido à lei. A outra inovação é a representatividade política, pela qual o poder legislativo passa a não ser mais constituído por uma oligarquia restrita, mas por toda a nação. (BOBBIO, 1995)

A filosofia anti-corrupção e as ideias associadas a ela são ligadas a esses processos históricos porque elas podem ser entendidas como a operacionalização jurídica do resultado alcançado por eles, ou seja, regras que busquem vincular o poder político ao Direito.

No discurso jurídico, um nível mais alto de generalidade normalmente é designado pela noção de princípios, que são regras de caráter geral cuja função típica não é orientar especificamente a ação concreta das pessoas, mas garantir a unidade e a coerência do sistema jurídico (ou de um subsistema particular, como o do direito administrativo). Desde a década de 1970, houve um desenvolvimento da ideia de que os princípios devem nortear toda a atuação jurídica, especialmente a própria interpretação das normas jurídicas. Embora haja uma série de debates sobre a devida caracterização dos princípios, há uma convergência no reconhecimento de que o papel discursivo por eles desempenhado é definido pelo seu maior grau de abstração, de modo que eles parecem impor deveres de forma genérica, sem definir pautas concretas de atuação. Assim, uma descrição mais típica do discurso jurídico da metodologia aqui adotada é a de que promovemos uma classificação de alguns princípios (entendidos como ideias programáticas que organizam o discurso) dentro de um mesmo conjunto, que chamamos de filosofia, utilizando a terminologia de Schmidt.

Neste sentido, a ideia de combate à corrupção foi classificada como filosofia devido ao seu caráter mais estável e abstrato. Firmar oposição à corrupção parece ser uma declaração autossuficiente. Não é necessário justifica-la por uma ideia maior. Mas o contrário geralmente ocorre, quando ideias menos abstratas e menos estáveis se justificam pela filosofia anticorrupção. Assim, a ideia pura de combate à corrupção é razoavelmente vaga, de modo que existem diversas ideias mais concretas associadas a ela. $\mathrm{Na}$ ordem política brasileira, a filosofia anti-corrupção está declarada na Constituição a partir de algumas dessas ideias, como a moralidade, a impessoalidade e a publicidade (CF/88, art. 37, caput).

Essas ideias exigem que a atuação estatal (especialmente as políticas públicas) adotem formatos específicos, impondo aos agentes do Estado uma série de padrões de conduta mais concretos, que designamos como programas e políticas. Interesse público, moralidade, impessoalidade e isonomia foram classificadas como programáticas, um pouco menos abstratas que a filosofia anti-corrupção. Já as ideias de rigidez, publicidade, transparência e controle social foram classificadas como políticas, por serem ideias organizadoras da atuação 
administrativa que se justificam a partir das ideias programáticas. Essas ideias têm a concretude necessária para que se desenvolva uma política pública específica (com políticas de transparência ou publicidade), embora permaneça o caráter transversal, já que essas são exigências aplicadas a qualquer atuação do Estado.

\section{Interesse público, moralidade, impessoalidade e isonomia}

Essas quatro ideias são velhas conhecidas no campo do Direito Administrativo. Muitos juristas já se dedicaram a discorrer sobre formas apropriadas de relacioná-las, classificá-las, desdobrá-las e explicá-las. Barroso (2007) sugere que o interesse público pode ser desdobrado em primário e secundário. Meirelles (2012) argumenta que a moralidade pode ser explicada a partir de conceitos como boa-fé objetiva e subjetiva. Di Pietro (2009) relaciona a impessoalidade com a ideia de finalidade. E Canotilho (2002) busca explicar a isonomia por meio das noções de igualdade material e real.

Entretanto, para os fins dessa pesquisa, consideramos mais adequado adotar uma abordagem mais simplificada. A ideia central seria o interesse público, que preconiza que a motivação dos atos públicos deve estar sempre acima dos interesses de particulares em geral. Como derivação do interesse público, a ideia de impessoalidade obriga o agente a retirar o seu interesse particular da motivação dos seus atos, agindo de forma impessoal. Além disso, a ideia de isonomia obriga o agente a retirar da motivação dos seus atos também o interesse de outros particulares, tratando todos os iguais da mesma forma. E por fim, a ideia de moralidade carrega a noção de que para um ato público ser lícito, não basta o mero requisito da legalidade, sendo necessário também que o ato seja motivado pelo interesse público.

\section{Rigidez}

O agente público frequentemente se depara com momentos em que é lícito decidir entre dois ou mais caminhos, bastando motivar a decisão de forma adequada. A dogmática do Direito Administrativo denomina discricionários atos com essa característica, em oposição àqueles atos em que não espaço para o exercício de juízos de conveniência e oportunidade, chamados de vinculados (DI PIETRO, 2009 e MEIRELLES, 2012).

A ideia de vinculação à lei se posiciona de forma contrária a esse possível espaço de liberdade decisória concedido pelas normas ao agente público, normalmente orientada pela ideia de que a devida atuação dos administradores é a de concretizar as escolhas políticas do legislador, e não a de fazer escolhas autônomas. Por isso, a ideia de vinculação ressalta a 
posição do agente público como seguidor de regras, de modo a evitar riscos de que a autoridade pública que lhe é conferida cause danos ao interesse público e ao princípio da legalidade, que determina que as pessoas somente podem ser obrigadas a fazer ou deixar de fazer algo em virtude de lei (ou seja, de decisões políticas tomadas por agentes politicamente legitimados).

Neste sentido, a ideia de vinculação sugere que o legislador, na defesa da ideia do interesse público, deve oferecer ao agente público um roteiro normativo tão completo e detalhado quanto possível, restringindo ao máximo a sua margem de ação, limitando a possibilidade de que o administrador paute sua conduta a partir de seus interesses pessoais. Este é o espírito da ideia que estamos chamando de rigidez no âmbito desta pesquisa.

\section{Controle social, publicidade, e transparência}

A ideia de controle social carrega a noção de que a coisa pública pode e deve ser controlada pela sociedade. Ao se inteirar sobre os atos públicos, cabe ao cidadão reagir com os recursos que ele tem para isso, seja por meio do seu voto para aprovar ou rejeitar determinado político, seja por outros mecanismos de controle social, como o mandado de segurança e a ação civil pública (DI PIETRO, 1993).

E para que a ideia de controle social possa ser materializada, é fundamental que as pessoas tenham conhecimento dos atos praticados pelos agentes públicos, o que nos leva às ideias de publicidade e transparência.

A publicidade é a ideia de que as informações relativas a qualquer ato público devem estar disponíveis para todos, exceto nos casos específicos em que o interesse público exigir um tratamento sigiloso de certas informações. Uma concretização dessa ideia é o princípio de que ninguém pode ser obrigado senão por regras conhecidas, o que exige a publicação das normas em documentos acessíveis a qualquer um, como os diários oficiais. O direito brasileiro declara o princípio da publicidade como regra geral, com algumas possibilidades de exceção, como a proteção da intimidade de particulares (art. $5^{\circ}, \mathrm{X}$ da Constituição Federal) ou situações de risco à segurança nacional (art. $5^{\circ}$, XXXIII da Constituição Federal).

Mais recentemente, a ideia de transparência vem sendo utilizada em complemento à publicidade, no sentido de que as informações públicas, além de disponibilizadas, também devem ser claras, transparentes. Essa é uma noção que busca evitar que os dados públicos sejam de difícil compreensão, seja por empregar linguagem excessivamente técnica ou por

utilizar formatos que não favorecem o seu uso pelos cidadãos. É nesse sentido que a Lei de 
Acesso à Informação (Lei $\mathrm{n}^{\circ}$ 12.527/2011) fala em informação "transparente, clara e em linguagem de fácil compreensão" em seu artigo $5^{\circ}$, por exemplo. 


\section{Capítulo 4: A filosofia pró-eficiência}

Esta filosofia e as ideias associadas a ela apresentaram mais afinidade com uma estrutura ideacional econômica baseada em imperativos capitalistas. Nestas ideias predominou uma linguagem gerencial, o que pode ser explicado pela vinculação dessas ideias a processos recentes de modernização administrativa do Estado brasileiro, especialmente ao paradigma gerencialista.

Embora a Constituição de 1988 tenha sinalizado no sentido de profissionalizar o serviço público, parte das medidas resultaram em aumento do corporativismo das carreiras públicas, com incorporação gratificações e benefícios, legislações que isolavam as carreiras da população e o estabelecimento de um modelo de previdência para os servidores públicos que era atuarialmente inviável e socialmente injusto. (ABRÚCIO, 2007)

Estes foram fatores que levaram a opinião pública a perceber que, apesar das inovações, ainda persistiam no funcionalismo público uma série de problemas históricos brasileiros, o que acabou legitimando a estratégia de Collor de colocar o servidor público (marajá) como o cerne dos problemas nacionais. Entretanto, foi no mandato do próprio Collor que se estabeleceu o regime jurídico único dos servidores, hoje considerado extremamente corporativista. (ABRÚCIO, 2007)

Sem grandes avanços no período Itamar, a administração pública passou por significativas iniciativas reformistas na gestão de Fernando Henrique Cardoso. Com o objetivo de construir uma nova gestão pública, nesta época foi criado o Ministério da Administração e Reforma do Estado, comandado pelo ministro Bresser-Pereira. Embora Bresser tenha sido pioneiro em perceber a necessidade de trazer ao Brasil as inovações observadas em vários lugares do mundo, nem sempre ele soube adaptar tais transformações às particularidades brasileiras. (ABRÚCIO, 2007)

A ideia central da tentativa de reforma comandada por Bresser era a de uma administração voltada para resultados, ou modelo gerencial, como era chamado na época. Apesar de muitas mudanças institucionais necessárias para alcançar o paradigma gerencial não terem sido alcançadas, o fato é que os movimentos reformistas causaram um choque cultural na burocracia brasileira. As ideias e noções relacionadas à visão gerencialista foram espalhadas por todo o país e não é difícil perceber a sua influência na atuação de agentes públicos. (ABRÚCIO, 2007)

A ideia de eficiência e outras associadas a ela derivam diretamente do paradigma gerencial, implantando de forma incompleta e tortuosa no Brasil, mas cujas ideias ainda 
produzem efeitos perceptíveis nos dias de hoje, como evidenciam as fontes pesquisadas neste trabalho. Semelhantemente à filosofia anti-corrupção, classificamos a ideia de eficiência como filosofia devido à sua natureza estável e abstrata. A ideia de eficiência parece declarar um valor em si. Geralmente, a sua defesa não precisa ser justificada a partir de uma ideia mais abstrata que ela mesma. Pelo contrário, a ideia de eficiência muitas vezes é empregada para justificar outras ideias, menos abstratas, menos estáveis. $\mathrm{Na}$ ordem política brasileira, o princípio da eficiência está explicitamente declarado no caput do art. 37 da Constituição Federal de 1988.

A ideia genérica de eficiência é razoavelmente vaga, de modo que existem diversas ideias mais concretas associadas a ela. No material analisado nesta pesquisa há uma série de referências a ideias ligadas a essa otimização, e que classificamos como programáticas por terem um grau intermediário de abstração: celeridade, economicidade, qualidade e segurança. Esses princípios, que são transversais por se aplicarem a toda a atuação governamental, exigem dos administradores uma série de comportamentos, que são caracterizados por ideias mais concretas e que classificamos como políticas: flexibilidade, autonomia, subjetividade, competitividade, gestão por resultados e inovação.

\section{Celeridade}

Essa dimensão da eficiência também encontra respaldo na ordem política brasileira, sendo mencionada explicitamente na Constituição (art. $5^{\circ}$, LXXVIII). Uma forma de explicar a ideia de celeridade é tomar emprestado o raciocínio da teoria dos custos de transação, elaborada por Coase (1937). De acordo com o autor, cada transação realizada no mercado tem um custo. Quando um agente incorpora um processo na sua própria organização, ele o faz para evitar o custo de transação de obter o mesmo resultado no mercado. Coase argumenta que é justamente para evitar os custos de transacionar no mercado que existem as firmas. Uma firma cresce até o limite em que o custo de incorporar processos em sua organização passa a ser maior que o custo transação de obter os mesmos resultados no mercado.

De forma análoga, a ideia de celeridade está relacionada à minimização de custos de transação. Entretanto, em processos governamentais, estes custos nem sempre estão associados a dinheiro. Muitas vezes, um caminho ou outro pode ser considerado mais eficiente do ponto de vista da celeridade em razão do fluxo decisório a ser percorrido. Por exemplo, para um governante, há menos custos de transação envolvidos em regular uma matéria por decreto em comparação a um envio de projeto de lei ao Congresso Nacional. O 
mesmo acontece na hipótese de uma contratação pública: se a cada fase da licitação houver um período destinado a recursos das empresas licitantes, há mais custos de transação envolvidos em comparação a um arranjo onde haja uma fase recursal única ao final da licitação. Quanto menos transações forem envolvidas nos processos governamentais, mais estará sendo valorizada a ideia de celeridade.

\section{Economicidade e qualidade}

A ideia de economicidade talvez seja a que mais se confunde com a própria ideia geral de eficiência. Dificilmente a noção de "gastar menos" se ausenta dos discursos sobre eficiência. Esta dimensão da eficiência também é valorizada explicitamente no art. 70 da Constituição. Embora seu uso seja intenso nos discursos pró-eficiência, seu conceito é muito simples. Basicamente, a economicidade preconiza que as coisas devem ser feitas ao menor custo possível.

Entretanto, se a economicidade fosse levada ao extremo, não é difícil supor que, na busca pelo menor custo possível, a queda de qualidade na prestação de serviços seria um

caminho fácil e certo. É no sentido de afastar essa hipótese extremista que entra em jogo a ideia de qualidade, relativizando e criando limites para a ideia de economicidade.

Um exemplo simples de emprego dessas ideias pode ser encontrado na comparação entre duas modalidades de licitação presentes na Lei Geral: melhor preço e melhor técnica e preço. A primeira delas busca exclusivamente o menor preço, privilegiando a ideia de economicidade. A outra busca combinar a economicidade com a ideia de qualidade, favorecendo resultados semelhantes ao que o ditado popular costuma descrever como "bom, bonito e barato".

\section{Segurança}

A ideia de segurança envolve a noção de que "incorrer em riscos ameaça a eficiência”. No âmbito das licitações públicas, essa ideia se traduz em evitar surpresas em contratações, pois há várias ocasiões em que a Administração pode ser surpreendida negativamente por parte de seus contratados.

Em uma contratação de obra pública, por exemplo, uma empresa contratada para executar a obra pode pedir revisão de preços para cima, alegando que a empresa que elaborou o projeto básico cometeu erros de estimativa. Outra possibilidade é a de que uma empresa apresente um cronograma de andamento de obra pública cujas fases iniciais representem 
parcela significativa da remuneração total, abandonando o projeto após a realização dessas fases, deixando a obra inacabada. Ainda é possível que uma empresa não consiga realizar o que prometeu ao vencer uma licitação, ficando para a Administração o ônus de lidar com essa incapacidade do contratado. (PESSOA NETO e CORREIA, 2015)

Todos estes exemplos ilustram situações em que a contratação gera ineficiências para a Administração, seja por necessidade de aumentar o custo da contratação por meio de aditivos, seja por atraso no andamento da obra por abandono do contratado ou por incapacidade do mesmo. Assim, a ideia de segurança surge no sentido de minimizar ou transferir esses riscos para terceiros. (PESSOA NETO e CORREIA, 2015)

\section{Flexibilidade, autonomia, subjetividade e inovação}

Estas quatro ideias costumam aparecer juntas nos discursos, embora às vezes apareçam de forma isolada, mesmo que guardem forte relação umas com as outras. A ideia de flexibilidade se refere à discricionariedade que um conjunto de normas oferece ao gestor público. Essa ideia envolve tanto o grau de abstração com o qual uma norma estabelece os limites de atuação do gestor quanto o leque de possibilidades que uma norma oferece a ele, a depender do caso concreto.

Estas flexibilizações podem ser exemplificadas com uma simples comparação entre a Lei Geral e o RDC ao estabelecerem, cada um, as suas modalidades de contratação. A Lei Geral descreve muito detalhadamente os critérios que definem quando cada modalidade será utilizada. Já o RDC oferece as suas modalidades, mas confia ao gestor a escolha no caso concreto, valorizando a ideia de autonomia, no sentido de que cabe a ele escolher e justificar a escolha, e a ideia de subjetividade, no sentido de que em um mesmo caso, nem todos fariam a mesma escolha. Finalmente, a ideia de inovação deriva justamente do maior grau de autonomia e subjetividade que uma norma mais flexível oferece ao gestor, favorecendo o surgimento de novas e melhores maneiras de fazer as coisas.

Parece ser em favor dessas ideias que alguns administrativistas falam em "leque de alternativas para a ação administrativa encontrar no Direito sua base e seus limites, mas sem comprometer a extensão da função criadora que a Administração tiver recebido da legislação, nos termos constitucionais”. (SUNDFELD, 2014, p. 235, grifo nosso) 


\section{Competitividade}

A competitividade é uma ideia mais restrita ao âmbito das contratações públicas, já que se refere à competição entre licitantes. Entretanto, é uma ideia que se relaciona com diversas dimensões da eficiência. Há a ideia de que o estímulo à competitividade tende a fazer com que a Administração consiga contratar por preços mais baixos, prestigiando a ideia de economicidade. Também há a ideia de que a competição entre licitantes favorece o surgimento de novas metodologias, prestigiando a ideia de inovação. Há ainda a ideia de que a competição estimula que os licitantes conheçam melhor o objeto licitado, favorecendo a ideia de qualidade. (PESSOA NETO e CORREIA, 2015)

\section{Gestão por resultados}

Esta é uma ideia presente em muitas teorias administrativas e que vem sendo relacionada ao setor público especialmente após o movimento que ficou conhecido como $\mathrm{New}$ Public Management (ABRÚCIO, 2005). A gestão por resultados é uma técnica específica de administrar organizações que desloca o foco do controle procedimental para a mensuração de resultados, dialogando com diversas dimensões da eficiência. Pelo menos em teoria, ao se preocupar mais com os fins que com os meios, esta forma de gestão busca minimizar custos de transação, privilegiando a ideia de celeridade, além de deixar o gestor mais livre para definir processos e procedimentos, valorizando as ideias de flexibilidade, autonomia, subjetividade e inovação. 


\section{PARTE III: OS DISCURSOS}

\section{Capítulo 5: $O$ orçamento sigiloso restrito à Anatel a partir de 1997}

Na segunda metade da década de 1990 o governo promoveu uma reforma no setor de telecomunicações cuja lógica geral era simples: o Estado abriria mão do seu papel de empresário, privatizando as estatais que atuavam na área, e assumiria a missão de regular o setor, criando uma institucionalidade voltada para isso (FERNANDES, 2010). Esta alteração foi introduzida na Constituição pela EC n. ${ }^{\circ}$ 8/1995, que previa "a criação de um órgão regulador" (CF/88, art. 21, XI), e concretizada em 1997 pela Lei no 9.742/1997, que instituiu a Agência Nacional de Telecomunicações (Anatel) e estabeleceu as bases do sistema regulatório do setor. Esse instrumento normativo foi gestado no Ministério das Comunicações (MC) e, depois de aprovado no Congresso Nacional, passou a ser conhecido como Lei Geral de Telecomunicações - LGT. (FERNANDES, 2010)

Esta lei estabeleceu para a Anatel um regime próprio de contratação. Dentre as inovações, estava a modalidade de licitação denominada Pregão, que permitia à Anatel o uso do orçamento sigiloso em suas contratações, o que inaugurou no ordenamento jurídico brasileiro a possibilidade de que os licitantes não tivessem acesso aos valores que a Administração estaria disposta a pagar por suas contratações, ainda restrita à Anatel. (FERNANDES, 2010)

O pregão da Anatel foi pensado para incorporar alguns elementos típicos do leilão à contratação de bens e serviços comuns cujo objeto pudesse ser facilmente definido. Os objetos que a agência desejava contratar seriam suficientemente descritos nos editais de divulgação dos pregões. Em seguida, os licitantes interessados apresentariam suas propostas e, depois, seriam chamados a formular lances em sessão pública. Definido o melhor lance, o pregoeiro ainda poderia negociar com o licitante para tentar melhorar as condições. Em nenhuma dessas fases os licitantes saberiam quanto a Anatel estaria disposta a pagar pela contratação, e é precisamente neste detalhe que reside o orçamento sigiloso nos pregões da Anatel.

Assim, o mecanismo do orçamento sigiloso não está declarado de forma explícita no caso da Anatel. O art. 55, II, da LGT se limita a listar os itens que devem obrigatoriamente fazer parte do instrumento convocatório de pregões da Anatel, e o orçamento estimado não é um desses itens. Já o art. $4^{\circ}, \S 2^{\circ}$, II da Lei Geral de Licitações e Contratos ordena de forma explícita que o orçamento faça parte dos editais de licitações regidos por ela. É essa diferença 
legislativa que fez com que o orçamento sigiloso fosse inserido na prática administrativa brasileira. Trata-se de medida um tanto quanto ambígua, visto que não houve um expresso afastamento da obrigatoriedade de publicação da estimativa orçamentária, o item foi apenas omitido.

Após a aprovação da LGT, quatro partidos de oposição ao governo da época (PT, PCdoB, PDT e PSB) ajuizaram a Ação Direta de Inconstitucionalidade nº 1.668 no Supremo Tribunal Federal (STF). A intenção era decretar a inconstitucionalidade de diversos pontos da lei, em especial aqueles que traziam inovações e flexibilidades ao governo, incluindo as regras específicas de contratação. Em decisão, os ministros do STF frustraram os oposicionistas e declararam a constitucionalidade do regime próprio de contratação da Anatel.

São três os discursos que exploraremos neste capítulo. O primeiro deles trata de como os políticos governistas enquadraram suas ideias para justificar o envio da LGT ao Congresso Nacional. Para isso, analisaremos trechos da Exposição de Motivos nº 231/1996 do Ministério das Comunicações. O segundo discurso trata das ideias utilizadas por políticos oposicionistas para tentar derrubar a LGT no STF. Neste caso, utilizaremos trechos da petição inicial da ADI $\mathrm{n}^{\mathrm{o}}$ 1.668. Por fim, o terceiro discurso trata de resposta dos ministros do STF ao pedido dos políticos oposicionistas. Para isso, examinaremos os votos do acórdão da ADI n 1.668.

Conforme já mencionado, a nossa busca por interações discursivas com ideias específicas sobre o orçamento sigiloso no âmbito da Anatel foi infrutífera. Os discursos a seguir defendem e atacam aspectos mais gerais de contratação trazidos pela LGT, e não o orçamento sigiloso em específico. Uma das possibilidades para explicar essa ausência de debate sobre o orçamento sigiloso talvez seja a própria forma implícita e ambígua com que o mecanismo foi inserido no contexto da Anatel, o que pode ter sido útil para não levantar polêmicas indesejadas sobre o tema. Contudo, consideramos que as ideias contidas nestas interações mais gerais serão úteis para sustentar as conclusões desta pesquisa, particularmente sobre o comportamento de políticos governistas e oposicionistas.

\section{O discurso dos políticos governistas para embasar a LGT}

O documento que justifica o envio da LGT ao Congresso é longo e cuida de cada item da lei. A análise será restrita aos aspectos relacionados às regras de contratação que a LGT estava inaugurando, neste primeiro momento, apenas para a Anatel. A ideia de flexibilidade é trazida já logo no início da seção para justificar as novidades nas regras de contratação. 
Em face mesmo da peculiar natureza da Agência Brasileira de Telecomunicações, concebida para atuar com a maior flexibilidade gerencial, não há como deixar de inovar quanto à disciplina de sua atividade contratual [...]. (Exposição de Motivos nº 231/1996 do Ministério das Comunicações, p. 45, grifos nossos)

O trecho a seguir reforça a ideia de inovação associada à sua origem gerencial, comparando o modelo proposto em relação ao que já existia no âmbito da Lei Geral:

Comparadas com as modalidades tradicionais de certames licitatórios evidenciam inovações que, em razão mesmo da experiência haurida com a aplicação da Lei nº.666/93, estão voltadas à implementação de um modelo gerencial de atuação do órgão regulador. (Exposição de Motivos $n^{\circ}$ 231/1996 do Ministério das Comunicações, p. 46, grifo nosso)

O documento faz a ressalva de que princípios clássicos de licitação continuarão a ser respeitados:

E este elenca regras que visam a assegurar a observância de princípios fundamentais como os da instrumentalidade das formas, vinculação ao instrumento convocatório do certame, julgamento objetivo, publicidade, devido processo, dentre outros. (Exposição de Motivos n ${ }^{\circ}$ 231/1996 do Ministério das Comunicações, p. 46, grifo nosso)

Essa ressalva é reforçada no trecho a seguir:

Em resumo, o Projeto confere à Agência autonomia para elaborar as regras disciplinadoras de suas licitações, estabelecendo, todavia, as necessárias balizas, de sorte a prestigiar o caráter cogente dos princípios e regras mais gerais a serem preservados. (Exposição de Motivos $n^{\circ}$ 231/1996 do Ministério das Comunicações, p. 46, grifo nosso)

Depois, a ideia de competitividade aparece associada às ideias de economicidade, qualidade e segurança:

Contém o Projeto, ainda, em seu art. 52, a premissa de que a finalidade do certame é, por meio de disputa justa entre interessados, obter um contrato econômico, satisfatório e seguro para a Agência. (Exposição de Motivos n 231/1996 do Ministério das Comunicações, p. 46, grifo nosso)

Aqui, aparece a ideia de subjetividade como elemento na avaliação das melhores propostas, bem como a ideia de celeridade associada à eficiência e à busca por resultados: 
Vê-se, portanto, que serão avaliados em conjunto os elementos subjetivos, objetivos e comerciais das propostas dos consultados, rompendo-se assim, também, com o tradicional modelo que separa nitidamente as fases de habilitação de licitantes e de classificação das propostas, na busca de maior rapidez e eficiência, e do melhor resultado. (Exposição de Motivos $n^{\circ}$ 231/1996 do Ministério das Comunicações, p. 46, grifo nosso)

E novamente, por fim, a ideia de celeridade:

Objetivando evitar burocratização, agilizar desempenho e usufruir de experiência profissional externa, a Agência poderá utilizar, mediante contrato, técnicos ou empresas especializadas, bem como consultores independentes e auditores externos [...]. (Exposição de Motivos nº 231/1996 do Ministério das Comunicações, p. 47, grifo nosso)

\section{O discurso dos políticos oposicionistas para tentar derrubar a LGT}

A petição questiona diversos pontos da LGT, de modo que a análise será restrita àqueles que se relacionam com regras de contratação. Ao tratar desse assunto, a petição começa articulando ideias que buscam defender o controle rígido e padronizado da regulamentação das licitações no Brasil. O caráter de controle das licitações é claramente valorizado:

A licitação é um dos mais importantes instrumentos de controle [...]. (ADI n ${ }^{\circ} 1.668$, petição inicial, p. 23, grifo nosso)

E o caráter constitucional dessas normas é "festejado":

Uma das mais festejadas inovações foi o disciplinamento das licitações e contratos administrativos em nível constitucional, efetuado pela primeira vez no Direito pátrio. (ADI no 1.668, petição inicial, p. 21, grifo nosso)

A petição lembra que é exclusiva da União a competência para legislar sobre normas gerais de licitação:

A Constituição atribuiu à União a competência privativa para legislar sobre normas gerais de licitações e todas as suas modalidades [...]. (ADI $\mathrm{n}^{\circ}$ 1.668 , petição inicial, p. 22, grifo nosso)

Valendo-se desse enquadramento inicial, a petição defende a ideia de rigidez associada às ideias de interesse público e isonomia, em claro combate à flexibilidade: 
Surgem normas gerais quando, por alguma razão, convém ao interesse público que certas matérias sejam tratadas por igual [...] para que se evite a coexistência de diversos procedimentos legais em face de uma mesma matéria, possibilitando tratamentos díspares de acordo com cada peculiar e distinta circunstância. (ADI n 1.668, petição inicial, p. 22, grifos nossos)

Em seguida, essas ideias de rigidez e isonomia serão utilizadas para justificar a impugnação de diversos pontos da LGT.

A regra que permite que a Anatel tenha regime próprio de contratação é contestada por meio das ideias de rigidez e isonomia:

Como afirmado alhures, objetivou o legislador constituinte criar uma unidade nacional no trato da matéria, posto se constituir a licitação de capital relevância para a Administração Pública. Uniformidade esta que traz segurança jurídica e certeza de procedimentos, tanto para a Administração quanto para o particular que com ela contrata. E o que objetivam os dispositivos atacados? Estabelecer um rompimento da ordem principiológica vigente, onde vários entes da administração agirão em cumprimento a determinado texto legal e outros, embora da mesma estrutura e natureza jurídica, terão a prerrogativa de atuar de forma livre e diferenciada. (ADI n ${ }^{\circ} 1.668$, petição inicial, p. 26, grifos nossos)

Aqui a ideia de isonomia é novamente utilizada, desta vez associada à competência legislativa da matéria restrita à Constituição, para combater o regime próprio de contratação da Anatel:

Rompe-se, de qualquer forma, com o comando normativo prescrito no inciso XXVII, do art. 22, da CF, cujo único entendimento é: a União deverá editar normas gerais de licitação, de observância obrigatória e, em decorrência disso, não permite a coexistência de vários dispositivos, uns gerais para determinados destinatários e outros, mais flexíveis e de aplicação legal questionável, para outra categoria de ente público. Nesse sentido, ou se muda o texto da Constituição, de forma a implantar a flexibilização ora pretendida pela Lei 9.472/97 ou se reprime com todas as forças jurídicas essas tentativas de burlar o texto da Lei Fundamental. (ADI n ${ }^{\circ} 1.668$, petição inicial, p. 27, grifos nossos)

A regra que atribui ao Conselho Diretor da Agência a aprovação de normas próprias de licitação é contestada:

[...] a prerrogativa trazida pela LGT outorga ao Conselho Diretor da Agência a competência para aprovar normas próprias de licitação e contratação. Ora, a competência para legislar em torno da matéria está cristalinamente definida na Lei Maior, cabendo privativamente à União e não ao Conselho 
Diretor da Agência ou a qualquer outro ente da Administração. (ADI $n^{\circ}$ 1.668 , petição inicial, p. 24, grifo nosso)

Por fim, a regra que permite que determinados tipos de consultor possam ser contratados sem licitação é questionada por meio da ideia de que tal flexibilidade estaria em afronta com a ideia de interesse público:

Empresas poderão ser contratadas, sob o pálio da inexigibilidade e, desta feita, conduzir as políticas da Agência, não voltadas para o interesse público, mas para os interesses dos grupos que os eventuais contratados poderão estar representando. (ADI $\mathrm{n}^{\circ} 1.668$, petição inicial, p. 28, grifos nossos)

$\mathrm{Na}$ conclusão, a petição defende explicitamente a ideia de combate a corrupção, argumentando que as mudanças que vinham acontecendo em diversos países não eram em função da necessidade de aumento da flexibilidade, mas sim da prevenção à corrupção:

[...] as mudanças pelo menos na legislação e nas práticas administrativas, de diversos países, se dão em razão da necessidade premente e inquestionável de se prevenirem e afastarem situações geradoras de corrupção [...]. (ADI $n^{\circ} 1.668$, petição inicial, p. 33, grifo nosso)

\section{O discurso dos ministros do STF em resposta aos políticos oposicionistas}

Em acórdão, os ministros do STF deliberaram sobre todos os pontos questionados pelos políticos oposicionistas em sua petição inicial, de modo que vamos nos ater apenas àqueles pontos examinados na seção anterior.

Em relação à possibilidade de a Anatel possuir um regime próprio de contratação, os ministros do STF decidiram de maneira contrária ao pedido dos políticos oposicionistas. A decisão final foi pela constitucionalidade do regime próprio da Anatel. O ministro Nelson Jobim, por exemplo, defendeu a ideia de que a chamada Lei Geral não seria geral, mas sim específica, afastando a obrigatoriedade de que todo regime de contratação tenha que estar alinhado a ela:

[...] a Lei $n^{\circ} 8.666$, que regulamentou essas normas de licitação, não tem nada de norma geral; não há espaço para o Estado disciplinar supletivamente [...]. (ADI n ${ }^{\circ} 1.668$, acórdão, p. 175, grifo nosso)

Assim, empregou a ideia de flexibilidade para fundamentar seu voto: 
Creio que o disposto no inciso acima não exclui, evidentemente, a possibilidade de determinados tipos de modalidades de licitações serem criadas em lei específica, principalmente considerando a especificidade da questão das telecomunicações. (ADI n ${ }^{\circ} 1.668$, acórdão, p. 174, grifo nosso)

Em relação à competência do Conselho Diretor da Anatel para aprovar normas próprias de licitação, os ministros do STF também decidiram contra o pedido dos políticos oposicionistas. O ministro Marco Aurélio, por exemplo, emprega a ideia de flexibilidade, argumentando que a competência do Conselho se refere às peculiaridades do setor, não afastando as leis gerais:

A competência ora atribuída ao Conselho Diretor não há de resultar no afastamento das normas gerais e específicas de licitação previstas nas leis de regência. Deve ficar restrita ao atendimento de peculiaridades inerentes aos serviços, sem prejuízo, portanto, do sistema de licitação, tal como existem na ordem jurídica em vigor. (ADI n ${ }^{\circ} 1.668$, acórdão, p. 165, grifos nossos)

O ministro Nelson Jobim emprega ideias semelhantes:

[...] no sistema de telecomunicações, que é algo de tecnologia de ponta, tem-se uma série de sistemas de transmissões de sinais novos que, para suas explicitações e licitações, requererão, nesses casos, normas específicas. (ADI $n^{\circ} 1.668$, acórdão, p. 166, grifos nossos)

E o ministro Octavio Gallotti argumenta na mesma linha:

Assim concluo por entender que a competência outorgada à Agência governamental em causa não é para editar normas de hierarquia legal, mas, sim, padrões de procedimento que devam observar as concessionárias de serviço público. (ADI $n^{\circ}$ 1.668, acórdão, p. 184, grifo nosso)

Por fim, em relação à contratação de consultores sem a necessidade de licitação, os ministros decidiram que o dispositivo não é inconstitucional, ficando a Anatel sujeita a observar a licitação, como regra, e a inexigibilidade apenas nos casos permitidos na Lei Geral: 
junho de 1993, ou seja, considerando-se como regra a ser observada, o processo licitatório [...]. (ADI n ${ }^{\circ} 1.668$, acórdão, p. 128, grifo nosso)

\section{Síntese}

Conforme procuramos mostrar, o discurso empregado pelos políticos governistas foi constituído predominantemente por ideias relacionadas à filosofia pró-eficiência, buscando fundamentar a necessidade das inovações trazidas pela LGT. Já o discurso dos políticos oposicionistas foi constituído em sua maioria por ideias relacionadas à filosofia anticorrupção, na tentativa de decretar a inconstitucionalidade da LGT. Por fim, no discurso dos ministros do STF prevaleceram as ideias pró-eficiência, de modo a sustentar a posição discursiva dos políticos governistas, garantindo, assim, a vigência da LGT. Seguem as sínteses analíticas desses discursos.

\section{Tabela 05 - Ficha analítica do discurso 01}

\begin{tabular}{|r|l|}
\hline Código & 01 \\
\hline Quem? & Políticos governistas (Ministro do MC, Governo PSDB) \\
\hline Para quem? & Congresso Nacional \\
\hline Onde? & Tramitação legislativa ordinária \\
\hline Como? & Via Exposição de Motivos \\
\hline Quando? & Na proposição da Lei \\
\hline O que? & Para justificar as inovações da Lei \\
(Principais & Flexibilidade \\
ideias) & $\begin{array}{l}\text { Anovação } \\
\text { Cutonomia } \\
\text { Competitividade } \\
\text { Economicidade } \\
\text { Qualidade } \\
\text { Segurança } \\
\text { Subjetividade } \\
\text { Celeridade } \\
\text { Eficiência }\end{array}$ \\
\hline Caráter geral \\
do discurso & Pró-eficiência \\
\hline
\end{tabular}


Tabela 06 - Ficha analítica do discurso 02

\begin{tabular}{|r|l|}
\hline Código & 02 \\
\hline Quem? & Políticos oposicionistas (PT, PCdoB, PDT e PSB) \\
\hline Para quem? & Ministros do STF \\
\hline Onde? & Em Ação Direta de Inconstitucionalidade \\
\hline Como? & Via Petição Inicial \\
\hline Puando? & Depois da aprovação da Lei \\
\hline Orincipais & Para decretar a inconstitucionalidade da Lei \\
ideias) & Isonomia \\
& Prevenção à corrupção \\
\hline Caráter geral & Anti-corrupção \\
do discurso & \\
\hline
\end{tabular}

Tabela 07 - Ficha analítica do discurso 03

\begin{tabular}{|r|l|}
\hline Código & 03 \\
\hline Quem? & Órgãos de controle (Ministros do STF) \\
\hline Para quem? & Políticos oposicionistas \\
\hline Onde? & Em Ação Direta de Inconstitucionalidade \\
\hline Como? & Via Acórdão \\
\hline Quando? & Depois do questionamento da constitucionalidade da Lei \\
\hline Por que? & Para decidir sobre a constitucionalidade da Lei \\
\hline Orincipais & \\
ideias) & \\
\hline Caráter geral & Pró-eficiência \\
do discurso & \\
\hline
\end{tabular}




\section{Capítulo 6: O orçamento sigiloso no Pregão a partir de 2000}

O segundo governo do Presidente Cardoso se deparou com uma crise financeira internacional que impactou negativamente a economia brasileira. Em resposta à crise, medidas de ajuste fiscal ganharam prioridade na agenda governamental, o que favorecia políticas com potencial de redução de despesas. (FERNANDES, 2010)

Neste contexto de restrição fiscal, dirigentes do Ministério do Planejamento, Orçamento e Gestão (MPOG) começaram a atuar na prospecção de inovações na área de compras e contratações, quando foi identificada a exitosa experiência da Anatel com o pregão. O MPOG elaborou então uma proposta para estender a modalidade à toda a administração pública federal e obteve apoio da Presidência da República. (FERNANDES, 2010)

Em moldes semelhantes ao pregão da Anatel, o Pregão geral foi instituído em 2000 por Medida Provisória (MPV) para a esfera federal. A tramitação foi longa, de modo que a MPV se converteu na Lei $n^{\circ} 10.520$ apenas em 2002, quando o Pregão foi estendido para todos os entes da federação.

É importante destacar que o mecanismo do orçamento sigiloso adotado pelo Pregão geral possui o mesmo grau de ambiguidade do Pregão da Anatel. Tanto as numerosas versões da MPV do Pregão quanto a própria Lei admitiram a possibilidade de uso do orçamento sigiloso ao deixar de declarar o orçamento como item obrigatório a constar no instrumento convocatório dos Pregões (art. $4^{\mathrm{o}}$, III).

Entretanto, ao se estender o Pregão para todos os entes da federação, ele passou a ser muito mais utilizado, e ampliou-se consideravelmente a visibilidade do mecanismo do orçamento sigiloso. Esta maior visibilidade associada à sua já existente ambiguidade parece ter criado as condições para o surgimento de novas interações discursivas sobre o orçamento sigiloso, conforme será demonstrado nas próximas páginas.

A seguir, analisaremos três grupos de manifestações discursivas. $\mathrm{O}$ primeiro deles se refere ao discurso dos políticos governistas para defender a nova modalidade de licitação, o Pregão. Para isso, utilizaremos a Exposição de Motivos nº 93/2000, do MPOG. Em seguida, faremos um breve exame sobre as propostas de emenda que a MPV do Pregão recebeu, no intuito de captar a reação dos políticos oposicionistas. Por fim, examinaremos o discurso do Tribunal de Contas da União (TCU) sobre o orçamento sigiloso no âmbito do Pregão. Para tanto, utilizaremos acórdãos referentes aos quatro casos onde o uso do orçamento sigiloso foi questionado. 


\section{O discurso dos políticos governistas para aprovar a Lei do Pregão}

A primeira MPV encaminhada ao Congresso Nacional sobre a matéria do Pregão foi acompanhada da Exposição de Motivos n 93/2000, elaborada pelo MPOG. Já no início, a ideia de competitividade aparece associada à ideia de economicidade:

O Projeto em questão objetiva aperfeiçoar o regime de licitações, com a inclusão de uma nova modalidade, denominada pregão, que possibilitará o incremento da competitividade e a ampliação das oportunidades de participação nas licitações, concorrendo para o esforço de redução de despesas indispensável ao cumprimento das metas de ajuste fiscal. (Exposição de Motivos $n^{\circ} 93 / 2000$ do Ministério do Planejamento, $\S 2^{\circ}$, grifos nossos)

A mesma combinação de ideias surge em outras passagens do documento:

Trata-se de modalidade que dá oportunidade à competição, ensejando o ajustamento das propostas com base no conhecimento mútuo das mesmas entre os contentadores, favorecendo a redução dos preços em benefício da Administração Pública Federal. (Exposição de Motivos no 93/2000 do Ministério do Planejamento, $\S 5^{\circ}$, grifos nossos)

A ideia de celeridade também é valorizada:

[...] o pregão resultará em maior agilidade nas aquisições, ao desburocratizar os procedimentos para a habilitação e o cumprimento da sequência de etapas da licitação. (Exposição de Motivos no 93/2000 do Ministério do Planejamento, $\S 2^{\circ}$, grifo nosso)

Aqui, surge a ideia de qualidade surge associada às ideias de economicidade e competitividade:

Estas economias poderão ser obtidas sem prejuízo da qualidade ou do volume de compras e contratações, uma vez que a redução de preços decorrerá do incremento da competição entre os fornecedores. (Exposição de Motivos $n^{\circ}$ 93/2000 do Ministério do Planejamento, $\S 7^{\circ}$, grifos nossos)

É interessante notar que a experiência então recente da Anatel é mencionada, com destaque para as ideias de economicidade e de celeridade: 
a tudo isso que a duração do processo licitatório tem sido encurtada em cerca de 20 dias. (Exposição de Motivos $n^{\circ}$ 93/2000 do Ministério do Planejamento, $\S 6^{\circ}$, grifos nossos)

Por fim, surgem ideias de transparência e controle social associadas ao uso de novas tecnologias, especialmente a internet:

[...] é extremamente oportuna a integração do processo de compras governamentais a este novo ambiente tecnológico, que possibilita maior transparência, controle social e oportunidades de acesso às licitações públicas. (Exposição de Motivos no 93/2000 do Ministério do Planejamento, $\S 11$, grifos nossos)

\section{As propostas de emenda dos políticos oposicionistas na MPV do Pregão}

Conforme já mencionado, a tramitação da MPV do Pregão foi longa. A Medida teve oito versões enquanto adotava o número 2026, depois assumiu outras sete versões sob o número 2108, e por fim mais três versões sob o número 2182.

Essas dezoito versões receberam um total de dezessete emendas parlamentares. Apenas três delas foram de políticos oposicionistas da época, tendo as três o mesmo conteúdo. Duas dessas emendas pertenciam ao Deputado Geraldo Magela e a outra pertencia ao Deputado Walter Pinheiro, ambos do PT.

A maioria das emendas propostas por políticos governistas tinha o objetivo de ampliar o Pregão para todos os entes nacionais, e não apenas a União, como previa a MPV. Essas emendas obtiveram sucesso por meio da aprovação da Lei do Pregão, que, de fato, regulamentou o Pregão para todos os entes.

Já o propósito das emendas dos políticos oposicionistas era levar a regulamentação do Pregão para o âmbito da Lei Geral. Para isso, eles fazem uso da ideia de rigidez em oposição à ideia de flexibilidade:

A introdução de mais uma modalidade de licitação na legislação pertinente não deve sê-lo por normatização à parte da Lei de Licitações $\mathbf{n}^{\mathbf{0}}$ 8.666 [...]. É nela e somente nela que as modificações devem ser efetuadas. Não sendo assim haverá motivos para inúmeros escapes à legislação específica por meio de artifícios legais dessa ordem. (Justificativa da Emenda Parlamentar n 03 à MPV 2026-1, grifos nossos)

É interessante notar que, apesar da omissão dos políticos oposicionistas em suas justificativas, se essa tentativa tivesse obtido êxito, teriam desaparecido do ordenamento 
jurídico os principais elementos de flexibilidade do Pregão, inclusive o orçamento sigiloso. Isso teria acontecido porque as suas emendas sugeriam apenas elencar o Pregão como modalidade de licitação na Lei Geral, deixando para trás as inovações procedimentais detalhadas nas sucessivas versões da MPV do Pregão.

\section{Discursos do TCU sobre o orçamento sigiloso no âmbito do Pregão}

Nesta seção, analisaremos o discurso do TCU a partir de acórdãos relacionados a quatro casos diferentes. Os casos se referem a todos aqueles encontrados na base ${ }^{12}$ do TCU em que houve discussão sobre a interpretação do instituto do orçamento sigiloso no âmbito do Pregão. A quantidade de casos pode parecer pequena, fato que se explica pelo fato de que após o TCU firmar posição sobre determinado assunto, dificilmente aparecem novas interações sobre aquilo para que o órgão aprecie.

O primeiro caso se refere a um Pregão realizado em 2001, com orçamento sigiloso, referente a fornecimento de vidros ao Ministério das Relações Exteriores (MRE). Em 2004, o TCU condenou o pregoeiro a pagar multa justamente pelo uso do orçamento sigiloso:

O Pregoeiro entendeu à época que a compatibilidade dos preços com o valor do mercado estava claramente prevista no edital e que os montantes ofertados seriam comparados com o levantamento de preços efetuado pela administração, o qual não foi divulgado às licitantes. A justificativa não procede, uma vez que os preços utilizados como parâmetros na avaliação dos preços cotados devem ser de conhecimento dos licitantes. (Acórdão TCU 254/2004 - Plenário, grifo nosso)

O pregoeiro, ao recorrer, argumentou que a prática do orçamento sigiloso em Pregões era ensinada na Escola Nacional de Administração Pública (Enap), além do fato de que o sistema Comprasnet recusava editais de Pregão contendo valores ou estimativa de preços:

Diz, ainda, que a não divulgação do levantamento de preõs efetuado pela Administração às licitantes foi em decorrência da interpretação dada pela Escola Nacional de Administração Pública - ENAP aos participantes do curso de formação de pregoeiros, fl. 34 , vol. 7 , e reforçado pela recusa do sistema Comprasnet aos editais contendo valores ou estimativa de preços. (Acórdão TCU 201/2006 - Plenário, grifos nossos)

\footnotetext{
${ }^{12}$ Disponível em http://portal.tcu.gov.br/
} 
Em análise, técnicos do TCU percebem que a irregularidade imputada ao pregoeiro foi feita com base na Lei Geral, e não na MPV que regulava o Pregão à época:

Inicialmente, percebemos que a irregularidade atribuída ao Recorrente baseou-se na Lei Geral de Licitações [...], embora o normativo específico aplicável à modalidade de pregão era, à época, a Medida Provisória [...]. (Acórdão TCU 201/2006 - Plenário)

Por fim, em voto, os ministros do TCU decidem adotar os argumentos do pregoeiro e retirar a multa a ele atribuída:

[...] sua conduta restou justificada ante as controvérsias jurídicas existentes quando da realização do pregão. (Acórdão TCU 201/2006 - Plenário, grifo nosso)

O próximo caso se refere a determinação feita em 2006 pelo TCU ao Serviço Federal de Processamento de Dados (Serpro) para que o órgão não adote o orçamento sigiloso em seus Pregões:

2. Determinar ao SERPRO que: [...] 2.3 nos procedimentos licitatórios para aquisição de produtos e contratação de serviços de informática, anexe aos instrumentos convocatórios o orçamento estimado em planilhas de quantitativos e preços unitários. (Acórdão TCU 664/2006 - Plenário, grifo nosso)

À época, o diretor-presidente do Serpro recorreu, empregando ideias de competitividade e de celeridade:

A anexação de orçamento [...] frustrará o caráter competitivo da licitação [...] implicará demora para a conclusão da licitação. (Acórdão TCU 1.925/2006 - Plenário, grifos nossos)

Técnicos do TCU se opõem a essas ideias por meio das ideias de isonomia e publicidade:

Há que se analisar também o próprio fim a que se destina o procedimento licitatório, qual seja, garantir a observância do Princípio da Isonomia e selecionar a proposta mais vantajosa para a Administração, observado, ainda, o Princípio da Publicidade. (Acórdão TCU 1.925/2006 - Plenário, grifos nossos) 
Os ministros do TCU, em linguagem bastante jurídica, discordaram dos técnicos e defenderam que a legislação do Pregão dá aos gestores a faculdade de optar pelo orçamento sigiloso, um argumento associado às ideias de autonomia e flexibilidade:

Não é cabível, então, defender que a exigência em comento é lícita apenas em decorrência de a Lei $n^{\circ} 8.666 / 1993$ a demandar, visto que esta norma somente é aplicável aos pregões de forma subsidiária e que, em relação a este tópico, a norma específica possui disciplinamento próprio o qual afasta o Estatuto das Licitações. Ressalto, contudo, que o presente entendimento não constitui uma vedação à anexação dos referidos orçamentos aos editais de pregões, uma vez que estes podem, a critério do gestor público, ser amplamente divulgados e, inclusive, integrar os editais publicados. (Acórdão TCU 1.925/2006 - Plenário, grifo nosso)

A determinação ao Serpro foi, portanto, retirada.

O caso seguinte se refere a um Pregão realizado em 2005 pelo Banco do Brasil para a confecção física de cartões de crédito. O banco optou pelo orçamento sigiloso, uma das causas pelas quais uma empresa licitante entrou com representação no TCU para anular o Pregão, que chegou a ser suspenso enquanto o TCU decidia.

A empresa licitante empregou ideias de isonomia e publicidade para alegar que o orçamento sigiloso impede a formulação de propostas:

Segundo a representante, o edital que regulamenta o certame estaria eivado de vícios que inibem indevidamente a competitividade e violam os princípios da publicidade e da isonomia entre os licitantes, a saber: (i) ausência de critérios mínimos para a fixação do preço máximo dos serviços licitados, sem a indicação do orçamento previsto e do preço máximo a ser aceito pelo Banco, o que impediria a formulação de propostas adequadas, competitivas e exequíveis [...]. (Acórdão TCU 114/2007 - Plenário, grifos nossos)

O banco se defende argumentando que o orçamento sigiloso é permitido pela legislação que regulamenta o Pregão:

[...] ressalta que a legislação que regulamenta o pregão não exige o detalhamento do orçamento [...]. (Acórdão TCU 114/2007 - Plenário)

Técnicos do TCU discordam do argumento do banco e valorizam a ideia de publicidade: 
[...] não nos parece sensato desprestigiar o princípio da publicidade e a transparência da gestão pública, cuja prática pela administração é enfaticamente defendida no Mapa Estratégico no TCU. (Acórdão TCU 114/2007 - Plenário, grifo nosso)

Além disso, defendem a ideia de isonomia em oposição à ideia de autonomia:

[...] não sendo obrigatória a divulgação do valor estimado, mas também não sendo proibida, mais difícil seria estabelecer o controle sobre a isonomia dos participantes em relação a tal divulgação. (Acórdão TCU 114/2007 Plenário, grifo nosso)

A partir dessas ideias, os técnicos do TCU sugeriram aos ministros que determinassem ao banco a divulgação do orçamento no Pregão. Em decisão, os ministros do TCU discordaram mais uma vez dos técnicos, empregando ideias de autonomia e flexibilidade:

Como visto, na licitação na modalidade pregão, o orçamento estimado em planilhas e preços unitários não constitui um dos elementos obrigatórios no edital [...]. Ficará a critério do gestor, no caso concreto, a avaliação da oportunidade e conveniência de incluir esse orçamento no edital [...]. (Acórdão TCU 114/2007 - Plenário, grifo nosso)

O último caso se refere a um Pregão realizado em 2005 pelo Ministério da Saúde (MS) para contratar serviços de transporte de funcionários. Uma empresa licitante entrou com representação no TCU reclamando que, dentre outros vícios, o edital optava pelo orçamento sigiloso:

O reclamante argumenta que [...] existe uma exigência nas licitações de que haja orçamento detalhado com a composição de todos os custos unitários. (Acórdão TCU 410/2006 - Plenário)

Técnicos do TCU concordam com a empresa licitante, valorizando a ideia de isonomia:

[...] devem ser especificados no Edital os preços unitários de forma a estabelecer critérios de aceitabilidade de dar igualdade de condições às licitantes. (Acórdão TCU 410/2006 - Plenário, grifo nosso)

Os ministros do TCU suspendem o Pregão e pedem justificativa pelo uso do orçamento sigiloso. O MS emprega a ideia de economicidade para justificar o orçamento sigiloso: 
[...] tal decisão está abraçada pelo princípio da economicidade, uma vez que as empresas, conhecendo os procedimentos de pesquisa de preços, não demonstram a realidade quando são consultadas antes de uma licitação, acarretando em conclusão de licitações com valores, às vezes, bem acima dos preços reais de mercado. (Acórdão TCU 1.405/2006 - Plenário, grifo nosso)

Mais uma vez os técnicos do TCU valorizam a ideia de publicidade para se posicionar contra o orçamento sigiloso:

[...] a Administração deve pautar-se observando o Princípio da Publicidade [...], razão pela qual não devem ser omitidas nos editais as estimativas de preços unitários e global. (Acórdão TCU 1.405/2006 - Plenário, grifo nosso)

E novamente os ministros do TCU discordam dos técnicos. Desta vez, além das ideias de autonomia e flexibilidade, também foram empregadas as ideias de economicidade e eficiência para defender o orçamento sigiloso:

[...] deve ficar a critério do gestor a decisão de publicá-las também no edital, possibilitando desse modo que adote a estratégia que considere mais eficiente na busca pela economicidade da contratação. (Acórdão TCU 1.405/2006 - Plenário, grifo nosso)

A justificativa do MS foi, portanto, acatada pelos ministros do TCU.

\section{Síntese}

Neste capítulo procuramos demonstrar que o discurso empregado pelos políticos governistas se caracterizou por ideias relacionadas à filosofia pró-eficiência no intuito de justificar a necessidade das inovações trazidas pelo Pregão. Já o discurso dos políticos oposicionistas, embora discreto, utilizou a ideia de rigidez para tentar derrubar os aspectos inovadores do Pregão. Por fim, técnicos e ministros do TCU discordaram em seus discursos. Enquanto os técnicos fizeram oposição ao orçamento sigiloso por meio de ideias de publicidade e isonomia, os ministros o defenderam empregando ideias de autonomia, flexibilidade, economicidade e eficiência. 
Tabela 08 - Ficha analítica do discurso 04

\begin{tabular}{|c|c|}
\hline Código & 04 \\
\hline Quem? & Políticos governistas (Ministro do MPOG, Governo PSDB) \\
\hline Para quem? & Congresso Nacional \\
\hline Onde? & Tramitação legislativa de Medida Provisória \\
\hline Como? & Via Exposição de Motivos \\
\hline Quando? & Durante a vigência de Medida Provisória \\
\hline Por que? & Para justificar as inovações da Medida Provisória e convertê-la em Lei \\
\hline $\begin{array}{r}\text { O que? } \\
\text { (Principais } \\
\text { ideias) }\end{array}$ & $\begin{array}{l}\text { Competitividade } \\
\text { Economicidade } \\
\text { Celeridade } \\
\text { Qualidade } \\
\text { Transparência } \\
\text { Controle social }\end{array}$ \\
\hline $\begin{array}{r}\text { Caráter geral } \\
\text { do discurso }\end{array}$ & Pró-eficiência \\
\hline
\end{tabular}

Tabela 09 - Ficha analítica do discurso 05

\begin{tabular}{|c|c|}
\hline Código & 05 \\
\hline Quem? & Políticos oposicionistas (PT) \\
\hline Para quem? & Congresso Nacional \\
\hline Onde? & Tramitação legislativa de Medida Provisória \\
\hline Como? & Via justificativa de proposta de emenda parlamentar \\
\hline Quando? & Durante a vigência de Medida Provisória \\
\hline Por que? & $\begin{array}{l}\text { Para tentar regulamentar o Pregão no âmbito da Lei Geral, o que teria como consequência o } \\
\text { desaparecimento das suas principais inovações procedimentais, inclusive o orçamento } \\
\text { sigiloso. }\end{array}$ \\
\hline $\begin{array}{r}\text { O que? } \\
\text { (Principais } \\
\text { ideias) }\end{array}$ & Rigidez \\
\hline $\begin{array}{r}\text { Caráter geral } \\
\text { do discurso }\end{array}$ & Anti-corrupção \\
\hline
\end{tabular}


Tabela 10 - Ficha analítica do discurso 06

\begin{tabular}{|r|l|}
\hline Código & O6 \\
\hline Quem? & Órgãos de controle (Técnicos do TCU) \\
\hline Para quem? & Ministros do TCU \\
\hline Onde? & Litígios sobre orçamento sigiloso no TCU \\
\hline Como? & Via relatórios técnicos citados em acórdãos do TCU \\
\hline Quando? & Antes das decisões dos ministros do TCU \\
\hline Por que? & Para tentar firmar interpretação de que o orçamento sigiloso não pode ser adotado. \\
Orincipais & Isonomia \\
ideias) & \\
\hline Caráter geral & Anti-corrupção \\
do discurso & \\
\hline
\end{tabular}

Tabela 11 - Ficha analítica do discurso 07

\begin{tabular}{|r|l|}
\hline Código & 07 \\
\hline Quem? & Órgãos de controle (Ministros do TCU) \\
\hline Para quem? & Toda a Administração Pública \\
\hline Onde? & Litígios sobre orçamento sigiloso no TCU \\
\hline Como? & Via votos em acórdãos do TCU \\
\hline Quando? & No momento das decisões \\
\hline Por que? & Para firmar interpretação de que o orçamento sigiloso é facultado ao gestor. \\
\hline Orincipais & Flexibilidade \\
& Economicidade \\
\hline $\begin{aligned} \text { Caráter geral } \\
\text { do discurso }\end{aligned}$ & Pró-eficiência \\
\hline
\end{tabular}




\section{Capítulo 7: O orçamento sigiloso no RDC a partir de 2011}

No início da década de 2010 o Brasil se preparava para desenvolver a infraestrutura necessária para sediar a Copa do Mundo em 2014 e os Jogos Olímpicos em 2016. Frente a esse desafio, abriu-se um debate sobre a possibilidade de adotar um regime especial de contratações que incorporasse as boas práticas já existentes, especialmente os procedimentos de licitação do Pregão e as regras de contratação das Concessões (Leis n ${ }^{\circ}$ 8.987/1995 e 9.074/1995) e das Parcerias Público-Privadas (Lei nº 11.079, de 30 de dezembro de 2004). (PESSOA NETO e CORREIA, 2015)

A primeira tentativa dos políticos governistas para aprovar o RDC foi durante a tramitação da MPV nº 488/2010, que criava a Autoridade Pública Olímpica. Não obtendo êxito, tentou-se mais uma vez no âmbito da MPV no 489/2010, também sem sucesso. Na terceira tentativa, conseguiu-se aprovar o RDC no âmbito da Lei de conversão da MPV n ${ }^{\circ}$ 527/2011 (Lei n ${ }^{\circ}$ 14.462/2011). (PESSOA NETO e CORREIA, 2015)

Neste primeiro momento, o escopo do RDC ainda era restrito a ações relacionadas aos eventos esportivos e a aeroportos próximos de cidades-sede da Copa do Mundo. Posteriormente, foi estendido para outras ações prioritárias do governo, como os empreendimentos do Programa de Aceleração do Crescimento, obras do Sistema Público de Ensino e do Sistema Único de Saúde, dentre outras possibilidades. (PESSOA NETO e CORREIA, 2015)

Diferentemente dos momentos anteriores, no RDC o mecanismo do orçamento sigiloso aparece de forma muito explícita na legislação, deixando pouca margem de interpretação sobre a sua existência. Já no caput o artigo $6^{\circ}$ da Lei do RDC afirma que "o orçamento previamente estimado para a contratação será tornado público apenas e imediatamente após o encerramento da licitação”. Além disso, o $\$ 3^{\circ}$ do artigo citado afirma que "se não constar do instrumento convocatório, a informação referida no caput deste artigo possuirá caráter sigiloso", o que suscita a discricionariedade sobre o uso do orçamento sigiloso, já que ele pode ou não constar do instrumento convocatório. Por fim, o referido parágrafo determina que a informação sigilosa "será disponibilizada estrita $e$ permanentemente aos órgãos de controle externo e interno", o que garante o acesso ao orçamento sigiloso pelos órgãos de controle.

Além do orçamento sigiloso, o RDC incorporou do Pregão a inversão de fases, a oferta pública de lances, a fase recursal única e a tramitação eletrônica. Entretanto, vale lembrar que por meio do RDC, estes mecanismos se tornaram disponíveis para contratações de grande 
vulto, como obras em portos, aeroportos, ferrovias e rodovias, o que não era permitido pelo Pregão. Além disso, o RDC incorporou das Concessões e das Parcerias Público-Privadas a contratação integrada, que permite que um mesmo contratado elabore o projeto básico de uma obra e o execute, bem como a remuneração variável, que permite que um contratado seja remunerado conforme critérios de desempenho previamente acordados. Trata-se de um modelo de contratação conhecido internacionalmente como design-build, previsto na legislação de diversos países, como nos Estados Unidos em seu Federal Aquisition Regulation, e nos membros da União Européia, a partir da Diretiva 2.018/2004 da União Européia. (PESSOA NETO e CORREIA, 2015)

Após a aprovação da Lei do RDC, a sua constitucionalidade foi questionada por duas ações diretas de inconstitucionalidade no STF, que buscaram declarar o RDC como inconstitucional, suspendendo a sua vigência até o julgamento. A primeira (ADI $n^{\circ} 4.645$ ) foi ajuizada por 3 partidos de oposição da época (PSDB, DEM e PPS) e a segunda (ADI n ${ }^{\circ}$ 4.655) foi ajuizada pelo Procurador-Geral da República, ambas foram distribuídas ao Ministro Luiz Fux e ainda aguardam julgamento sem que haja liminar pendente.

Neste capítulo, exploraremos três manifestações discursivas. $\mathrm{Na}$ primeira delas buscaremos captar as ideias utilizadas por políticos oposicionistas para desqualificar as inovações do RDC, inclusive o orçamento sigiloso. Para isso, analisaremos trechos da petição inicial da $\mathrm{ADI} \mathrm{n}^{\circ}$ 4.645. Em seguida, procuraremos captar as ideias empregadas por políticos governistas para defender as inovações do RDC, incluindo o orçamento sigiloso. Neste caso, examinaremos trechos do Parecer n 2.903/2011 da Subchefia de Assuntos Jurídicos (SAJ) da Casa Civil (CC) e da Prestação de Informações no 113/2011 da Advocacia-Geral da União (AGU). Por fim, buscaremos captar as ideias do TCU sobre questões práticas direcionadas ao orçamento sigiloso. Para isso, analisaremos trechos de acórdãos onde o Tribunal se manifesta sobre o assunto.

\section{O discurso dos políticos oposicionistas para tentar derrubar o RDC}

Inicialmente, os partidos argumentam que o texto original da MPV que recebeu o RDC via emenda parlamentar não atenderia os pressupostos de relevância e urgência exigidos pela Constituição:

[...] originalmente, a medida provisória em exame tratava apenas da reorganização da Presidência da República e Ministérios, tema ordinário 
que não autoriza o emprego de medidas provisórias. Afinal, nada mais comum e ordinário do que a reestruturação de órgãos e reorganização da Administração Pública. (ADI n ${ }^{\circ} 4.645$, petição inicial, p. 3, grifo nosso)

Em seguida, argumentam que houve abuso no poder de emendar em duas dimensões. Primeiro pelo fato de que o RDC seria matéria estranha à MPV original:

Em primeiro lugar, cumpre asseverar que a tramitação da Medida Provisória n. 527 e do respectivo Projeto de Lei de Conversão no Congresso Nacional não observou o devido processo legislativo constitucional, tendo em vista a admissão de emendas absolutamente impertinentes ao texto da Medida Provisória n. 527/2011. (ADI n ${ }^{\circ} 4.645$, petição inicial, p. 6, grifo nosso)

A outra dimensão do abuso no poder de emendar estaria no fato de que inserir matéria relevante como o RDC via emenda parlamentar retiraria a possibilidade de que o RDC sofra outras emendas, já que não é possível que um parlamentar emende matérias incluídas por relatores em plenário:

[...] o direito de emendar, por sua vez, também resta impedido, por força das constrições regimentais que impedem o oferecimento de emendas por parlamentares em matérias novas incluídas em plenário pelo relator da proposição. (ADI n ${ }^{\circ} 4.645$, petição inicial, p. 20)

Em seguida, os partidos começam a argumentar contra o mérito do RDC. De maneira geral, utilizam ideias de moralidade e isonomia para iniciar seus argumentos:

[...] os novos instrumentos que institui não são capazes de assegurar a moralidade administrativa e a garantia da isonomia entre os participantes da licitação, que são elementos fundamentais do conceito constitucional de licitação. (ADI n 4.645 , petição inicial, p. 26, grifo nosso)

Os partidos utilizam ideias de rigidez para argumentar contra as ideias de flexibilidade e autonomia do RDC:

Observa-se, assim, verdadeira delegação de competência a ente da Administração Pública para definir o regime licitatório aplicável ao caso. Ou seja, na prática, o Executivo poderá escolher, caso a caso, o regime jurídico aplicável. A falha é grave [...]. (ADI $n^{\circ} 4.645$, petição inicial, p. 28, grifo nosso) 
Os partidos utilizam ideias de moralidade e impessoalidade para argumentar contra a possibilidade que o RDC traz de o contratado ser remunerado de forma variável conforme o desempenho:

Não é condizente com os princípios da moralidade administrativa e da impessoalidade deixar ao gestor púbico a opção sobre os valores a serem pagos aos contratados. Decerto que esse mecanismo, em lugar de estimular a eficiência dos contratos, fomentará relações promíscuas entre o público e o privado. (ADI $n^{\circ} 4.645$, petição inicial, p. 40, grifos nossos)

Os partidos criticam a regra que permite que alguns atos sejam publicados apenas na internet, empregando ideias de publicidade, moralidade e controle social:

[...] ao mitigar a publicidade dos atos a que se refere [...], põe em risco também a moralidade administrativa [...]. A supressão de instrumentos de publicidade, tal como a publicação pela imprensa oficial, reduz também a possibilidade de eficácia de controle social, enfraquecendo o princípio constitucional da moralidade. (ADI $n^{\circ} 4.645$, petição inicial, p. 44, grifos nossos)

Por fim, os partidos empregam ideias de publicidade e transparência para atacar o orçamento sigiloso:

De acordo com tal disposição, se a informação não constar do instrumento convocatório, presume-se que seja sigilosa. Há nisso uma inversão da regra constitucional. Na Constituição Federal a publicidade e a transparência são regra [...]. De acordo com a Constituição, o sigilo não se presume, justifica-se. (ADI no 4.645, petição inicial, p. 46, grifos nossos)

\section{O discurso dos políticos governistas para defender o RDC}

A AGU começa argumentando que o poder de emendar do Congresso Nacional não está limitado à matéria correlata ao instrumento original:

O certo é que o Texto Constitucional não apresenta nenhum dispositivo que proíba a medida provisória de vir a ser acrescida de normas sobre temas diferenciados ou sem afinidade com o seu texto primitivo. (Prestação de Informações nº 113/2011 da AGU, § 19, grifos nossos)

$\mathrm{O}$ argumento é reforçado pelo fato de tramitar à época proposta para emendar a Constituição justamente para estabelecer essa regra: 
Observe-se, mais, que, com o objetivo de tornar a afinidade temática exigível, há Proposta de Emenda à Constituição em curso no Congresso Nacional [...]. (Prestação de Informações nº 113/2011 da AGU, § 21)

Sobre a questão dos pressupostos da relevância e da urgência, a AGU cita jurisprudência do STF que confia aos poderes Executivo e Legislativo o julgamento do mérito:

No que concerte à alegada falta dos requisitos da relevância e da urgência da Medida Provisória [...], quando dependa de uma avaliação subjetiva, estritamente política, mediante critérios de oportunidade e conveniência, está confiada aos Poderes Executivo e Legislativo, que têm melhores condições que o Judiciário para uma conclusão a respeito. (Prestação de Informações $n^{\circ} 113 / 2011$ da AGU, § 24, grifos nossos)

Em seguida, ao tratar das questões de mérito sobre o RDC, a AGU aproveita as ideias empregadas pela $\mathrm{SAJ} / \mathrm{CC}$ em seu parecer.

Inicialmente, a Casa Civil busca enquadrar o RDC como uma das opções disponíveis para o gestor público, de forma paralela à Lei Geral e à Lei do Pregão, um argumento que valoriza as ideias de flexibilidade e autonomia:

Afirma-se, portanto, que o regime diferenciado de contratações tratado pela Lei $\mathrm{n}^{\mathrm{o}} 12.462$, de 05 de agosto de 2011, e a Lei $\mathrm{n}^{\mathrm{o}}$ 8.666, de 21 de junho de 1993, são modelos diferentes de contratação pública, sendo facultado à Administração, motivadamente e dentro das balizas legais, optar por um deles [...]. O mesmo ocorre com a Lei $\mathrm{n}^{\circ}$ 10.520, de 17 de julho de 2002, que dispõe que para aquisição de bens e serviços comuns poderá ser adotada a modalidade pregão [...]. Assim como a Lei $\mathrm{n}^{\circ} 10.520$, de 2002, a Lei $\mathrm{n}^{\circ}$ 12.462 de 2011 não revogou a Lei $\mathrm{n}^{\circ} 8.666$ de 1993, tão-somente estabeleceu um procedimento alternativo. (Parecer $n^{\circ}$ 2903/2011 da SAJ/CC, § 9, §11, §12, grifos nossos)

A Casa Civil argumenta que o modelo do RDC valoriza as ideias de eficiência e de gestão por resultados:

Dito isso, a Lei $\mathrm{n}^{\circ} 12.462$ de 2011 entra em vigência em um contexto de concretização do princípio da eficiência nas contratações públicas e da gestão pública por resultados, respeitados os demais princípios constitucionais, de forma a aproveitar as boas práticas já existentes na legislação brasileira, tais como o procedimento do pregão, e os casos internacionais bem-sucedidos. (Parecer $n^{\circ}$ 2903/2011 da SAJ/CC, § 14, grifo nosso) 
De forma geral, a Casa Civil emprega as ideias de celeridade, economicidade e competitividade para defender inovações do RDC:

[...] estímulo à informatização do processo licitatório, com vistas a acelerar os procedimentos [...]. A inversão da ordem das fases de habilitação e julgamento como regra geral, diminuindo a burocracia e reduzindo o custo para os participantes [...]. A combinação dos modos de disputa, abertas ou fechadas, estimulando a concorrência e aumentando os ganhos da Administração [...]. A instituição de fase recursal única, economizando tempo [...]. A instituição da pré-qualificação permanente, do sistema de registro de preços e do catálogo eletrônico de padronização, dando celeridade ao processo (Parecer $n^{\circ}$ 2903/2011 da SAJ/CC, § 15, grifos nossos)

A Casa Civil emprega ainda as ideias de transparência para defender as inovações do RDC:

[...] a Lei $\mathrm{n}^{\circ} 12.462$ de 2001 eleva a transparência do processo de contratação e promove o aperfeiçoamento dos mecanismos de controle, uma vez que, ao estimular a ampla utilização de meios e procedimentos eletrônicos, conforme dispõe em seu artigo 13, possibilita aos órgãos de controle o acompanhamento das licitações em tempo real e acesso a todos os seus detalhes. (Parecer $n^{\circ}$ 2903/2011 da SAJ/CC, § 16, grifo nosso)

A Casa Civil combina as ideias de flexibilidade, inovação e eficiência ao defender a modalidade de contratação integrada:

Com maior liberdade no planejamento e execução das obras, o contratante pode adotar soluções inovadoras, incorporar métodos mais eficientes e emprestar à obra pública - e indiretamente à Administração - o know-how do setor privado. (Parecer n ${ }^{\circ}$ 2903/2011 da SAJ/CC, § 32, grifo nosso)

A Casa Civil também emprega a ideia de economicidade para defender a modalidade de contratação integrada:

Há ainda mais segurança quanto aos custos. Sob a Lei $n^{\circ} 8.666$ de 1993, o valor contratado pode, muitas vezes, não corresponder à quantia paga ao fim do contrato, em razão dos sucessivos aditivos. Pela contratação integrada, o preço inicial da contratação será o efetivamente desembolsado pela Administração ao final do contrato. (Parecer n $n^{\circ}$ 2903/2011 da SAJ/CC, § 41, grifos nossos)

Para defender a possibilidade de remuneração variável, a Casa Civil usa ideias de eficiência e gestão por resultados: 
O referido instrumento, assim como todo diploma legal, busca a concretização do princípio da eficiência nas contratações públicas, inserido em um modelo de gestão pública por resultados. (Parecer $\mathrm{n}^{\circ}$ 2903/2011 da SAJ/CC, § 47, grifos nossos)

A Casa Civil valoriza a ideia de publicidade ao defender a adoção da internet para a divulgação de certos atos licitatórios no âmbito do RDC:

Vale destacar que a concretização do princípio da publicidade é muito mais efetiva com a divulgação dos atos públicos na rede mundial de computadores do que na publicação impressa via Diário Oficial. (Parecer $n^{\circ}$ 2903/2011 da SAJ/CC, § 53, grifo nosso)

Por fim, a Casa Civil emprega ideias de competitividade e economicidade para defender o orçamento sigiloso. Abaixo surge a ideia de competitividade:

A não divulgação do orçamento estimado para os participantes durante a licitação [...], buscando evitar conluios e outras práticas anticoncorrenciais. (Parecer $n^{\circ}$ 2903/2011 da SAJ/CC, § 15, grifo nosso)

No trecho a seguir aparece a ideia de economicidade:

Conforme se observa na prática, quando os licitantes possuem a informação acerca do montante que a Administração Pública está disposta a gastar, o valor dos lances apresentados fica condicionado pelo orçamento divulgado, desestimulando a apresentação de suas melhores propostas. Quando os licitantes não conhecem, de fato, o orçamento estimado, há tendência à apresentação de ofertas mais atrativas para a Administração. (Parecer $n^{\circ}$ 2903/2011 da SAJ/CC, § 59, grifo nosso)

Em seguida a Casa Civil argumenta que o orçamento sigiloso não afronta as ideias de publicidade e de transparência:

[...] em respeito aos princípios da publicidade e da transparência, os órgãos de controle terão total acesso às informações durante o processo licitatório, inclusive aos valores estimados pela Administração. Imediatamente após a apresentação das propostas, os valores estimados serão divulgados normalmente. (Parecer $n^{\circ}$ 2903/2011 da SAJ/CC, § 63, grifo nosso) 


\section{O discurso do TCU sobre questões práticas do orçamento sigiloso}

Nesta seção examinaremos o discurso dos ministros do TCU a partir de três casos que envolveram questões práticas sobre o orçamento sigiloso: o possível antagonismo entre economicidade e celeridade, as possibilidades de revisão do orçamento sigiloso durante a licitação e a admissibilidade da quebra de sigilo do orçamento em favor da celeridade.

O primeiro caso se refere a uma fiscalização feita pelo Tribunal para atualizar informações sobre ações do governo para a Copa do Mundo. Foi constatado, então, que a licitação para a reforma da pista do aeroporto de Confins, feita com orçamento sigiloso, havia fracassado em razão das propostas dos licitantes estarem acima dos preços estimados pela Administração.

Ao comentar o ocorrido, o TCU fornece a sua própria interpretação sobre o orçamento sigiloso. Inicialmente, o TCU valoriza a ideia de competitividade em relação à ideia de transparência:

$\mathrm{O}$ orçamento fechado, no RDC, foi pensado em prestígio à competitividade dos certames [...]. Nesse caso, em termos do princípio fundamental licitatório - o da obtenção da melhor proposta - a isonomia e a competitividade compensariam possível perda de transparência no que se refere à publicação dos preços estimativos. (Acórdão TCU 3.011/2012 Plenário, § 69, grifo nosso)

Em seguida, o TCU argumenta que há obras com preços mais previsíveis e obras com preços menos previsíveis:

Obras rodoviárias, por exemplo, possuem, tradicionalmente, mais serviços referenciados pelo Sicro. São menos encargos possíveis e maior a previsibilidade do preço-base. Obras portuárias e aeroportuárias, ao contrário, tem a característica de possuírem, via de regra, serviços relevantes - e complexos - não passíveis de parametrização direta com o Sinapi. (Acórdão TCU 3.011/2012 - Plenário, § 72 e § 73)

Nestes casos de maior imprevisibilidade, o TCU argumenta que tanto a Administração quanto as empresas licitantes deverão fazer estudos para chegar a uma estimativa de preços. Assim, o TCU argumenta que a imprevisibilidade desses estudos pode levar ao fracasso da licitação:

Esses estudos podem resultar em preços maiores ou menores que os do edital; e isso é tão mais verdade, quanto mais complexo e mais oneroso for o serviço. Se o mercado entender como maiores aqueles encargos, existirá 
uma grande possibilidade de fracasso no certame licitatório, por preços ofertados superiores aos valores paradigma. (Acórdão TCU 3.011/2012 Plenário, § 74)

Com base nesse risco, o TCU argumenta que a escolha do gestor público pelo orçamento sigiloso, que visa principalmente a dimensão econômica da eficiência, deve estar subordinada também a outras dimensões da eficiência, como a celeridade:

Concluo, então, que, como o sigilo no orçamento-base não é obrigatório, e pelo dever de motivação de todo ato, se possa recomendar à Infraero que pondere a vantagem, em termos de celeridade, de realizar procedimentos com preço fechado em obras mais complexas [...]. (Acórdão TCU 3.011/2012 - Plenário, § 75)

É interessante notar que, dentre todas as manifestações discursivas analisadas por esta pesquisa, esta foi a única em que a ideia de celeridade foi usada como possível limitadora da ideia de economicidade.

O caso seguinte se refere a uma fiscalização feita na Empresa Brasileira de Infraestrutura Aeroportuária (Infraero). Ao solicitar acesso ao orçamento sigiloso de uma licitação de obras no aeroporto de Porto Alegre, o TCU obteve resposta de que o orçamento estava sendo atualizado, mesmo a licitação já estando em fase externa.

Técnicos do TCU argumentaram que, via de regra, o orçamento sigiloso só poderia ser alterado na fase interna da licitação:

Diante dessa manifestação, a equipe de fiscalização arguiu o órgão que o procedimento, apensar de reconhecido como preventivo, não coadunava com os procedimentos de licitação estabelecidos pela Lei 12.462/2011 [...], tendo em vista que as revisões necessárias deveriam ter sido feitas na fase interna da licitação, e não na fase externa. (Acórdão TCU 3.366/2012 Plenário, grifo nosso)

Surge, portanto, a questão sobre o quão estático deveria ser o orçamento sigiloso:

A pergunta que se faz, diante da situação, é: até quando poderia a administração alterar um orçamento sigiloso? (Acórdão TCU 3.366/2012 - Plenário, grifo nosso)

Os ministros do TCU, reconhecendo que a Administração deve ter flexibilidade para alterar o orçamento sigiloso caso julgue necessário, admite essa possibilidade em fase externa, desde que os órgãos de controle sejam avisados tempestivamente: 
[...] é ilegal a revisão do orçamento fechado durante a fase externa da licitação sem a tempestiva disponibilização à equipe de auditoria [...]. (Acórdão TCU 3.366/2012 - Plenário)

O último caso se refere a uma denúncia feita por técnicos do TCU sobre uma possível quebra de sigilo do orçamento em uma licitação de obras no aeroporto de Salvador. O que levantou a desconfiança dos técnicos do TCU foi o fato de que o preço final ofertando em lance por uma empresa tinha um valor muito próximo do preço estimado pela Administração em seu orçamento sigiloso:

Causa estranheza o fato de, após decorridos quatorze dias da primeira contraproposta, tendo a empresa ofertado nesse intervalo proposta intermediária de preços, haver oferta final de preço praticamente igual ao valor orçado pela administração, com desconto irrisório. A ocorrência pode apontar para quebra de sigilo do orçamento, em benefício da empresa, com decorrente prejuízo para a Infraero, no que tange à possibilidade de obtenção de proposta mais vantajosa. (Acórdão TCU 306 /2013 - Plenário, § 18, grifos nossos)

Os ministros do TCU não acatam a denúncia dos técnicos e empregam ideias de eficiência e de celeridade para admitir quebra de sigilo na fase de negociação:

De modo objetivo [...] existem situações em que não vislumbro como manter, de modo judicioso e a estrito rigor, o sigilo na fase de negociação. Se a "menor proposta" for superior ao valor máximo admitido, existem duas possibilidades: a primeira é de, na fase de negociação, a licitante abaixar sucessivamente seu preço para tentar atingir a "cota" permitida, em um processo de tentativas e erros - quase um jogo de "quente e frio". Na prática, o "sigilo" seria quebrado no exato momento em que o preço atingir o teto da contratação. Nessa hipótese, a manutenção do sigilo só tornou o processo mais moroso, situação que, na busca pela eficiência (princípio explícito do RDC), inclusive no que se refere ao tempo para contratação, pareceme um contrassenso. (Acórdão TCU $306 / 2013$ - Plenário, § 18, grifos nossos)

\section{Síntese}

Neste capítulo demonstramos que no discurso dos políticos governistas predominaram ideias mais ligadas à filosofia pró-eficiência para sustentar as inovações trazidas pelo RDC. Já o discurso dos políticos oposicionistas estava recheado de ideias anti-corrupção para tentar derrubar o RDC em sua totalidade. Por fim, ministros do TCU firmam posição favorável ao orçamento sigiloso no âmbito do RDC a partir de ideias pró-eficiência, adotando inclusive posturas que pareceram mais ousadas que a dos próprios políticos governistas. Os ministros 
do TCU parecem ter colocado a ideia da celeridade em primeiro lugar tanto em relação à ideia de economicidade quanto em relação a própria proteção do sigilo orçamentário até o fechamento do negócio.

\section{Tabela 12 - Ficha analítica do discurso 08}

\begin{tabular}{|r|l|}
\hline Código & 08 \\
\hline Quem? & Políticos oposicionistas (PSDB, DEM e PPS) \\
\hline Para quem? & Ministros do STF \\
\hline Onde? & Ação Direta de Inconstitucionalidade \\
\hline Como? & Via petição inicial \\
\hline Quando? & Depois da aprovação da Lei do RDC \\
\hline Por que? & Para tentar derrubar a Lei do RDC \\
(Principais & Moralidade \\
ideias) & Isonomia \\
& Rigidez \\
& $\begin{array}{l}\text { Impessoalidade } \\
\text { Publicidade } \\
\text { Transparência } \\
\text { Controle social }\end{array}$ \\
\hline Caráter geral & Anti-corrupção \\
do discurso & \\
\hline
\end{tabular}

Tabela 13 - Ficha analítica do discurso 09

\begin{tabular}{|r|l|}
\hline Código & 09 \\
\hline Quem? & Políticos governistas (AGU e SAJ/CC, Governo PT) \\
\hline Para quem? & Ministros do STF \\
\hline Onde? & Ação Direta de Inconstitucionalidade \\
\hline Como? & Via prestação de informações \\
\hline Quando? & Depois da aprovação da Lei do RDC \\
Por que? & Para tentar manter a Lei do RDC \\
Orincipais & $\begin{array}{l}\text { Flexibilidade } \\
\text { Autonomia })\end{array}$ \\
Eficiência \\
Gestão por resultados \\
Celeridade \\
Economicidade \\
Competitividade
\end{tabular}




\begin{tabular}{|r|l|}
\hline & $\begin{array}{l}\text { Inovação } \\
\text { Transparência } \\
\text { Publicidade }\end{array}$ \\
\hline $\begin{array}{r}\text { Caráter geral } \\
\text { do discurso }\end{array}$ & Pró-eficiência \\
\hline
\end{tabular}

Tabela 14 - Ficha analítica do discurso 10

\begin{tabular}{|r|l|}
\hline Código & 10 \\
\hline Quem? & Órgãos de controle (Ministros do TCU) \\
\hline Para quem? & Toda a Administração Publica \\
\hline Onde? & Casos concretos sobre o orçamento sigiloso \\
\hline Como? & Via votos em acórdãos \\
\hline Quando? & No momento das decisões \\
\hline Por que? & Para firmar interpretação sobre questões práticas do orçamento sigiloso \\
Orincipais & Competitividade \\
ideias) & Eeleridade \\
& Fliciexncia \\
\hline $\begin{array}{r}\text { Caráter geral } \\
\text { do discurso }\end{array}$ & Pró-eficiência \\
\hline
\end{tabular}




\section{DISCUSSÃO DOS RESULTADOS E CONCLUSÃO}

Governos democráticos são permeados por uma constante tensão entre promoção da eficiência e combate à corrupção. Por um lado, as pessoas pressionam os governantes para que eles operem o Estado com o máximo possível de eficiência, o que demanda estruturas ágeis, flexíveis e adaptáveis. De outro, as pessoas cobram uma atuação republicana e sem desvios éticos, o que demanda uma série de mecanismos estatais de freios e contrapesos.

Quando se desloca muita energia do Estado para o controle de suas próprias atividades, há risco de se comprometer a eficiência. Em contrapartida, quando é insuficiente a energia deslocada para os freios e contrapesos estatais, há risco de se comprometer a atuação republicana. Esta tensão leva ao desenvolvimento de discursos anti-corrupção e próeficiência no interior do Estado.

O propósito geral desta pesquisa foi investigar a relação entre essas duas perspectivas discursivas. Os objetos examinados foram delimitados em torno das regras de contratações com orçamento sigiloso. O horizonte temporal analisado se refere aos três momentos em que este mecanismo surgiu nos regimes de contratação. O ângulo de análise adotado foi o embate discursivo entre políticos governistas, políticos oposicionistas e agentes de órgãos de controle, no intuito de compreender como os discursos que afirmavam o primado de uma perspectiva considerava a outra.

Em licitações com orçamento sigiloso, os participantes não sabem previamente o quanto a Administração pretende gastar no negócio, de modo que eles precisam formular as suas propostas sem essa informação. O orçamento sigiloso é adotado por regras de contratações na Europa e nos Estados Unidos, além de ser recomendado pela divisão anticartéis da OCDE. No Brasil, este mecanismo surgiu em três regimes diferentes. Primeiramente, no regime de contratações da Anatel, em 1997. Depois, no âmbito do Pregão, em 2000. Por último, no RDC, em 2011.

Em 1997, o país vivia uma reforma no setor de telecomunicações, quando o governo enviou ao Congresso Nacional um projeto de lei que criava a Anatel e concedia a ela um regime próprio de contratação. O discurso justificador do projeto de lei estava recheado de ideias pró-eficiência. Uma das novidades era a modalidade de licitação denominada Pregão, que permitia à nova agência o uso do orçamento sigiloso em suas contratações. O mecanismo não está declarado de forma explícita no caso da Anatel. A norma elenca os itens que devem fazer parte do instrumento convocatório de pregões, de modo que o orçamento estimado não aparece como um desses itens obrigatórios. Após a aprovação da lei, quatro partidos 
oposicionistas da época - PT, PCdoB, PDT e PSB - entraram com uma ADI no STF para decretar a inconstitucionalidade de diversos pontos da lei, em especial aqueles que traziam inovações e flexibilidades ao governo, incluindo as regras específicas de contratação. $\mathrm{Na}$ petição inicial dos partidos de oposição predominavam as ideias anti-corrupção. Por fim, na decisão dos ministros do STF prevaleceram as ideias pró-eficiência, de modo a declarar a constitucionalidade do regime próprio de contratação da Anatel.

Em 2000, o cenário era de restrição fiscal, o que favorecia políticas com potencial de reduzir despesas. Neste contexto, o MPOG identificou a experiência exitosa da Anatel com o Pregão. Fundamentado por ideias pró-eficiência, o governo amplia a modalidade para todos os órgãos federais via Medida Provisória (MPV). Durante a tramitação do projeto de conversão da MPV, o PT propõe emendas para migrar a modalidade do Pregão para o âmbito da Lei Geral, o que deixaria para trás a maioria das inovações da MPV, inclusive o orçamento sigiloso. As emendas não prosperaram e em 2002 a MPV foi convertida em lei, estendendo o Pregão para todos os entes da federação.

O orçamento sigiloso do Pregão geral é tão ambíguo quanto no caso da Anatel. A norma admite o seu uso ao deixar de exigir o orçamento estimado como item a constar no instrumento convocatório dos Pregões. Entretanto, ao se estender o Pregão para todos os entes da federação, ele passou a ser muito mais utilizado, e ampliou-se consideravelmente a visibilidade do mecanismo do orçamento sigiloso. Esta maior visibilidade associada à sua já existente ambiguidade parece ter criado as condições para o surgimento de interações discursivas no TCU sobre a interpretação da norma do orçamento sigiloso. Nas interações analisadas, o discurso dos técnicos do TCU se caracterizou predominantemente por ideias anti-corrupção, com efeitos concretos nas decisões intermediárias do Tribunal, como a suspensão de licitações e condenação inicial de pregoeiros. Já no discurso dos ministros do TCU foram encontradas muitas ideias pró-eficiência, várias delas usadas para reverter as medidas preventivas sugeridas pelos técnicos no andamento dos processos.

Por fim, o orçamento sigiloso surge em 2011 com a aprovação do RDC, quando o Brasil se preparava para desenvolver a infraestrutura necessária para sediar a Copa do Mundo em 2014 e os Jogos Olímpicos em 2016. Diferentemente dos momentos anteriores, no RDC o mecanismo do orçamento sigiloso apareceu de forma muito explícita na lei, deixando pouca margem de interpretação sobre a sua existência. Logo após a aprovação do RDC, partidos de oposição da época - PSDB, DEM e PPS - questionaram a sua constitucionalidade no STF fundamentados por ideias anti-corrupção. A defesa do governo contra as alegações dos oposicionistas foi caracterizada por ideias pró-eficiência. Até o momento da finalização desta 
pesquisa o STF ainda não havia se pronunciado a respeito da ação, de modo que não se sabe se ela vai ser reconhecida ou julgada pelo Tribunal. A posição do TCU sobre o orçamento sigiloso no âmbito do RDC também foi analisada e se caracterizou por ideias pró-eficiência.

\section{Padrões de interações discursivas}

Entre os momentos pesquisados, encontramos assimetrias nos padrões de interações discursivas que parecem ter sido influenciados tanto por fatores institucionais quanto agênticos, conforme a Tabela 15:

\section{Tabela 15 - Fatores institucionais e agênticos}

\begin{tabular}{|c|l|l|l|}
\cline { 2 - 4 } \multicolumn{1}{c|}{} & \multicolumn{1}{c|}{ Interação principal } & \multicolumn{1}{c|}{ Fatores institucionais } & \multicolumn{1}{c|}{ Fatores agênticos } \\
\hline $\begin{array}{c}\text { Momento } \\
\text { Anatel } \\
\text { (A partir de 1997) }\end{array}$ & $\begin{array}{l}\text { Debate no STF sobre a } \\
\text { constitucionalidade de } \\
\text { normas mais gerais, sem } \\
\text { especificar o orçamento } \\
\text { sigiloso. }\end{array}$ & $\begin{array}{l}\text { Norma do orçamento } \\
\text { sigiloso ambígua e de } \\
\text { aplicação restrita }\end{array}$ & $\begin{array}{l}\text { Juristas falaram no lugar dos } \\
\text { políticos oposicionistas. }\end{array}$ \\
\hline $\begin{array}{c}\text { Momento } \\
\text { Pregão } \\
\text { (A partir de 2000) }\end{array}$ & $\begin{array}{l}\text { Debate no TCU sobre a } \\
\text { existência da norma do } \\
\text { orçamento sigiloso. }\end{array}$ & $\begin{array}{l}\text { Norma do orçamento } \\
\text { sigiloso ambígua e de } \\
\text { aplicação ampla }\end{array}$ & $\begin{array}{l}\text { Os agentes falaram por si } \\
\text { mesmos. }\end{array}$ \\
\hline $\begin{array}{c}\text { Momento } \\
\text { RDC }\end{array}$ & $\begin{array}{l}\text { Debate no STF sobre a } \\
\text { constitucionalidade da } \\
\text { norma do orçamento } \\
\text { (A partir de 2011) }\end{array}$ & $\begin{array}{l}\text { Norma do orçamento } \\
\text { sigilosiloso explícita e de } \\
\text { aplicação ampla }\end{array}$ & $\begin{array}{l}\text { Juristas falaram no lugar dos } \\
\text { políticos oposicionistas. } \\
\text { Técnicos da área jurídica do } \\
\text { Executivo falaram no lugar } \\
\text { dos políticos governistas. }\end{array}$ \\
\hline
\end{tabular}

Os fatores institucionais da ambiguidade e da amplitude de alcance da norma parecem ter ajudado a produzir diferentes tipos de interações discursivas. Nos dois primeiros momentos, a maneira pela qual o orçamento sigiloso foi inserido nas normas apresentava grau significativo de ambiguidade. Assim, a questão da constitucionalidade da norma em si não foi objeto de interações entre políticos governistas e oposicionistas. Por outro lado, tal ambiguidade parece ter produzido interações discursivas no TCU no sentido de interpretar a própria existência da norma, especialmente no momento Pregão, cuja amplitude de alcance da norma era bem maior que no momento Anatel. Já no caso do RDC, a regra do orçamento sigiloso foi explicitada na lei de forma muito clara, produzindo interações discursivas no STF sobre a sua constitucionalidade em si, deixando pouca margem interpretativa para o TCU, que deliberou apenas sobre questões práticas da aplicação da norma. 
Também encontramos assimetrias que parecem estar mais relacionadas a fatores agênticos organizados em torno da vontade de sucesso do discurso. Neste sentido, encontramos discursos proferidos por juristas (petições iniciais feitas ao STF), por técnicos (técnicos do TCU e do Executivo Federal) e, naturalmente, por agentes essencialmente políticos (ministros do Executivo Federal, do TCU e do STF). Cada um desses discursos parece ter sido pensado em torno de conceitos muito semelhantes ao que Schmidt (2008) elenca como fatores de sucesso do discurso, descritos por ela como as coisas certas (a norma existe? a norma é constitucional?), ditas pelas e para as pessoas certas (juristas, políticos, técnicos?), da forma certa (petição, acórdão, exposição de motivos?), no lugar certo (TCU, STF?).

Estes achados da pesquisa parecem sustentar a reivindicação de Schmidt (2008) de que aspectos institucionais e agênticos ajudam a produzir diferentes desenhos de interações discursivas.

\section{O comportamento dos agentes}

Ideias associadas à filosofia pró-eficiência foram encontradas em maior quantidade nos discursos de políticos governistas e do alto escalão dos órgãos de controle, como os ministros do TCU e do STF. Já as ideias associadas à filosofia anti-corrupção foram mais encontradas nos discursos de políticos oposicionistas e de técnicos do TCU. A Tabela 16 traz uma síntese destes resultados.

Tabela 16 - Síntese do caráter geral dos discursos

\begin{tabular}{|c|c|c|c|}
\cline { 2 - 4 } \multicolumn{1}{c|}{} & Políticos governistas & Políticos oposicionistas & Órgãos de controle \\
\hline $\begin{array}{c}\text { Momento } \\
\text { Anatel } \\
\text { (A partir de 1997) }\end{array}$ & $\begin{array}{c}\text { Pró-Eficiência } \\
\text { (Ministro do MC, } \\
\text { Governo PSDB) }\end{array}$ & $\begin{array}{c}\text { Anti-corrupção } \\
\text { (PT, PCdoB, PDT e PSB) }\end{array}$ & $\begin{array}{c}\text { Pró-Eficiência } \\
\text { (Ministros do STF) }\end{array}$ \\
\hline $\begin{array}{c}\text { Momento } \\
\text { Pregão } \\
\begin{array}{c}\text { A partir de 2000) } \\
\text { (Ministro do MPOG, } \\
\text { Governo PSDB) }\end{array}\end{array}$ & $\begin{array}{c}\text { Anti-corrupção } \\
\text { (PT) }\end{array}$ & $\begin{array}{c}\text { Anti-corrupção } \\
\text { (Técnicos do TCU) }\end{array}$ \\
\hline $\begin{array}{c}\text { Momento } \\
\text { RDC } \\
\text { (A partir de 2011) }\end{array}$ & $\begin{array}{c}\text { Pró-Eficiência } \\
\text { (AGU e SAJ/CC, } \\
\text { Governo PT) }\end{array}$ & $\begin{array}{c}\text { Pró-Eficiência } \\
\text { (Ministros do TCU) }\end{array}$ \\
\hline
\end{tabular}


Em relação aos políticos, observou-se que os governistas tenderam a usar mais os discursos pró-eficiência e os oposicionistas tenderam a usar mais os discursos anti-corrupção, independentemente da posição que ocupavam no espectro partidário. Nos dois primeiros momentos pesquisados, a coalizão governista era liderada pelo PSDB. Já no momento RDC, a coalizão era liderada pelo PT. Entretanto, foi possível observar que os discursos governistas presentes nesses três momentos estavam organizados a partir de ideias similares. De forma análoga, foi possível observar semelhança entre os discursos de políticos oposicionistas empregados no momento Anatel, com participação do PT, e aqueles empregados no momento RDC, com participação do PSDB.

Assim, outro achado relevante da pesquisa é que discursos anti-corrupção e próeficiência não estavam associados, necessariamente, a grupos com determinadas ideologias políticas. Pelo contrário, eles pareceram se associar mais à posição institucional (situação ou oposição) que cada grupo político assumia em cada momento analisado.

Do ponto de vista teórico, este achado parece sustentar as reivindicações de Schmidt (2008) de que os agentes não se comportam como meros reprodutores de ideias sobre regras institucionais, ainda que estejam vinculados a essas ideias. Os agentes parecem ter procurado empregar ideias em seus discursos a partir do que eles interpretaram como seus interesses em cada momento, comportamento muito semelhante ao que Schmidt (2008) denomina de habilidades ideacionais e discursivas. Assim, as ideias não funcionaram apenas como referencial que enquadra a ação, mas também como elementos que, quando bem articulados em um discurso, ajudam a sustentar esta ou aquela ação.

Sob o olhar mais geral da pesquisa, a atuação de políticos oposicionistas pode ser entendida como um dos mecanismos de freios e contrapesos a ser enfrentada pelos governos. Esta atuação se caracterizou majoritariamente por ideias anti-corrupção nos três momentos pesquisados. Como grande parte da energia dos políticos oposicionistas pareceu estar concentrada em proteger o interesse público de eventuais malfeitos, houve muito pouca consideração destes políticos pela eficiência administrativa. Este achado, embora restrito ao recorte desta pesquisa, suscita questões tanto teóricas, sobre o papel da oposição em função da eficiência, quanto empíricas, sobre a regularidade com que o fenômeno aqui percebido pode ser encontrado em outros casos.

No tocante aos agentes de órgãos de controle, observamos que os técnicos do TCU tenderam a empregar mais os discursos anti-corrupção, ao passo que os ministros do TCU e do STF tenderam a usar mais os discursos pró-eficiência. No âmbito do TCU, foi observado que as decisões finais proferidas pelos ministros foram revestidas por discursos pró- 
eficiência. Entretanto, na fase intermediária dos processos, parece ter predominado uma postura mais anti-corrupção no TCU, derivada dos discursos de seus técnicos, inclusive com efeitos suspensórios para a Administração. Assim, outro achado da pesquisa é que parece ter havido uma dinâmica discursiva no TCU que fez com que suas decisões intermediárias produzissem efeitos concretos em sentido contrário ao que as suas decisões finais iriam defender, e essa dinâmica parece ser produzida por divergências ideacionais entre técnicos e ministros do Tribunal.

Do ponto de vista teórico, o discurso dos técnicos do TCU pareceu estar constantemente alinhado à filosofia anti-corrupção, o que a primeira vista os colocaria como meros reprodutores de ideias sobre regras. Por outro lado, uma explicação mais agêntica seria a de que eles mantiveram os seus discursos inalterados não porque eles estivessem apenas seguindo regras, mas porque em cada caso analisado eles entenderam, a partir de ideias sobre interesses, regularidades históricas ou normas culturais, que estes eram os discursos que eles deveriam empregar. Entretanto, para se firmar uma conclusão assim, seria necessário aprofundar mais esta parte da pesquisa, talvez com a condução de entrevistas ou questionários. Já o discurso de agentes de alto escalão de órgãos de controle foi mais caracterizado por ideias pró-eficiência, o que sugere que eles foram capazes de empregar suas habilidades ideacionais e discursivas ao discordarem de seus técnicos, no caso dos ministros do TCU, ou dos políticos oposicionistas, no caso dos ministros do STF.

Do ponto de vista geral da pesquisa, a atuação de TCU também pode ser entendida como um mecanismo de freios e contrapesos. A posição anti-corrupção dos técnicos produziu efeitos concretos para a Administração, como a suspensão da licitação do BB, a condenação inicial do pregoeiro do MS e a determinação preventiva ao Serpro. Embora estes efeitos tenham sido revertidos ao final dos processos, quando os ministros entraram em ação com seus discursos pró-eficiência, não se pode deixar de notar o poder que os técnicos tiveram no sentido de obstruir a eficiência administrativa. Isso sugere que nem sempre as decisões finais do TCU são suficientes para entender a atuação do órgão, já que ele parece ser capaz de operar em sentido contrário à eficiência por meio de suas decisões intermediárias. Este achado também suscita questões teóricas sobre o papel do TCU em função da eficiência, além de questões empíricas sobre a regularidade com que isso acontece.

Como os propagadores de discursos anti-corrupção consideram a eficiência e como os propagadores de discursos pró-eficiência consideram o controle? 
Posições ponderadas entre a promoção da eficiência e o combate à corrupção poderiam ter tido efeitos muito produtivos nos momentos pesquisados, mas não observamos esse tipo de equilíbrio na pesquisa. Pelo contrário, a tensão discursiva entre a necessidade de eficiência estatal e as amarras dos mecanismos de freios e contrapesos se mostrou muito ativa. Entretanto, o conflito parece residir em nível bem mais sutil que o pressuposto pela pergunta de pesquisa. As ideias mais gerais de combate à corrupção e de promoção à eficiência parecem ser abstratas demais para entrar em confronto direto. Entretanto, ideias mais concretas associadas a essas filosofias podem ser incompatíveis, como as ideias de rigidez e flexibilidade, por exemplo.

Os resultados mostraram que os agentes não declararam o primado de uma ou outra filosofia, como foi pressuposto na pergunta inicial de pesquisa. Ainda assim, o ato de privilegiar uma filosofia específica ocorreu precisamente quando os agentes empregaram ideias mais concretas que se associavam a tal filosofia, mas que eram incompatíveis com ideias ligadas à outra filosofia.

Uma reivindicação teórica de Schmidt (2008) que parece ter encontrado sustentação nessas observações é a que distingue os discursos entre coordenativos e comunicativos. Os agentes não parecem ter combatido propriamente a filosofia oposta, limitando-se a defender ideias mais específicas. Essa espécie de economia discursiva parece configurar um discurso de autoridade, de quem decide (discurso coordenativo), e não de quem precisa convencer alguém (discurso comunicativo).

Outra reivindicação de Schmidt (2008) diz respeito ao fato de que os discursos podem se beneficiar de certo grau de abstração. Nos discursos observados, aquele que prioriza a rigidez, por exemplo, pode estar comprometendo a eficiência, ainda que se declare favorável a ela. Da mesma forma, aquele que enfatiza a flexibilidade pode dificultar o combate à corrupção, ainda que defenda este combate. Em um nível mais abstrato, parece ser razoavelmente possível se equilibrar entre ideias de eficiência administrativa e de combate à corrupção. Entretanto, ao detalhar estes discursos, nem sempre é fácil manter a posição equilibrada.

Esta última consideração traz implicações importantes para que se possa fazer observações mais cuidadosas do mundo social e político. O discurso parece revelar a real posição de seu portador tanto quanto as ideias articuladas por ele sejam mais especificas. Deste modo, parece ser fundamentalmente útil examinar com cautela todo discurso fundado apenas em filosofias gerais, muitas delas hegemônicas no interior do Estado, como por exemplo a democracia, o combate à corrupção, a gestão por resultados ou o planejamento 
estratégico. Em um nível mais abstrato, estes discursos podem sinalizar em uma direção muito diferente da realidade, que só parece se revelar por meio de aspectos mais específicos ligados aos discursos. O discurso democrático pode revelar-se plutocrático quando é sustentando por regras que dificultam o acesso de grupos menos favorecidos ao poder. $\mathrm{O}$ discurso contra a corrupção pode escondê-la quando é proferido por seus praticantes. O discurso da gestão por resultados pode inviabilizá-los quando as regras de mensuração se tornam mais importantes que os próprios resultados. E o discurso do planejamento estratégico pode se dissolver em metas impossíveis quando regras operacionais impedem o seu alcance.

Como diria Mano Brown, "o veneno vem na sopa". E é com base neste raciocínio que o título deste trabalho é uma pergunta que exige uma escolha única entre rigidez e flexibilidade, políticas mais específicas, e não entre promoção da eficiência e combate à corrupção, filosofias mais gerais. É preciso encarar os detalhes. Especificar o geral. Descer do estratégico para o operacional. Inverter a pirâmide. Ou esquecê-la. 


\section{REFERÊNCIAS}

ABRÚCIO, Fernando Luiz. Os avanços e o dilema do modelo pós-burocrático. In: BRESSER-PEREIRA, Luiz Carlos e SPINK, Peter (Org.). Reforma do Estado e Administração Pública Gerencial. 6ª Edição. São Paulo: FGV, 2005, p. 171-199.

Trajetória recente da gestão pública brasileira: um balanço crítico e a renovação da agenda de reformas. Revista de Administração Pública, V. 41, p. 67-86, 2007.

BARROSO, Luis Roberto. Prefácio à obra Interesses Públicos versus Interesses Privados: desconstruindo o principio de supremacia do interesse publico. $2^{\mathrm{a}}$ tiragem. Editora Lúmen Júris. Rio de Janeiro, p. 13-14, 2007.

BERK, Gerald; GALVAN, Dennis; HATTAM, Victoria. Beyond Dualist Social Science: The Mangle of Order and Change. In: BERK, Gerald; GALVAN, Dennis; HATTAM, Victoria (Org.). Political Creativity: Reconfiguring Order and Change. Philadelphia: University Of Philadelphia Press, 2013, p. 1-28.

BLYTH, Mark M. Any more bright ideias? The ideational turn in Comparative Political Economy. Comparative Politics, V. 29, p. 229-250, 1997.

BOBBIO, Norberto. O Positivismo Jurídico: Lições de filosofia do direito. São Paulo: Ícone, 1995.

BOURDIEU, Pierre. Esboço de uma teoria da prática. In: ORTIZ, Renato (Org.). Sociologia. São Paulo: Ática, 1983. p. 60-81.

Introdução a uma sociologia reflexiva. In: BOURDIEU, Pierre. O Poder Simbólico. Rio de Janeiro: Bertrand Brasil, 2007, p. 17-58.

CAMPBEL, John L., PEDERSEN, Ove K. The Rise of Neoliberalism and Institutional Analysis. Princeton: Princeton University Press, 2001.

CANOTILHO, José Joaquim Gomes. Direito constitucional e teoria da constituição. 6. ed. Portugal: Almedina, 2002.

COASE, Ronald. The nature of the firm. Economica, v. 386, n. 2, p. 386-405, 1937.

DI PIETRO, Maria Sylvia Zanella. Direito Administrativo. São Paulo: Ed. Atlas, 2009.

Participação popular na Administração Pública. Revista Trimestral de Direito Público, São Paulo, Malheiros, v. 1, p. 127-139, 1993.

EMIRBAYER, Mustafa; MISCHE, Ann. What is Agency? American Journal of Sociology, Chicago, v. 103, p. 962-1023.

FERNANDES, Ciro Campos Christo. Política de compras e contratações: trajetória e mudanças na administração pública federal brasileira. Tese de Doutorado. Fundação Getúlio Vargas, 2010.

GIDDENS, Anthony. Dualidade da Estrutura, Agência e Estrutura. Oeiras, Portugal: Celta Editora, 2000.

HALL, Peter A; TAYLOR, Rosemary C. R. Political science and the three new institutionalisms. Political Studies, 1996.

HALLET, Tim; VENTRESCA, Marc. Inhabited institutions: Social interactions and organization forms in Gouldner's Patterns of Industrial Bureaucracy. Theory and Society, V. 35, p. 213-236, 2006. 
HAY, Colin. Constructivist Institutionalism. In: RHODES, R. A. W; BINDER, S. A.; ROCKMAN, B. A.. The Oxford Handbook of Political Institutions. Oxford: Oxford University Press, 2006. p. 56-74.

JABKO, Nicolas. Playing the Market: A Political Strategy for Uniting Europe, 19852005. Ithaca: Cornell University Press, 2006.

JOAS, Hans. Intelligence and Reconstruction. In: JOAS, Hans; GAINES, Jeremy; KEAST, Paul. The Creativity of Action. Chicago: University Of Chicago Press, 1996. p. 126-145.

KING, Gary; KEOHANE, Robert; VERBA, Sidney. Designing Social Inquiry: Scientific Inference in Qualitative Research. New Jersey: Princeton University Press, 1994.

LAWRENCE, Thomas; SUDDABY, Roy; LECA, Bernard. Theorizing and Studying Institutional Work. In: LAWRENCE, Thomas; SUDDABY, Roy; LECA (Org.). Institutional Work: Actors and Agency in Institutional Studies of Organizations. Cambridge: Cambridge University Press, 2009. p. 1-27.

MAHONEY, James. After KKV: The New Methodology of Qualitative Research. World Politics, v. 62, n. 1, pp. 120-147, 2010.

MEIRELLES, Hely Lopes. Direito Administrativo Brasileiro. São Paulo: Ed. Medeiros, 2012.

PERES, Paulo Sérgio. Comportamento ou instituições? A evolução histórica do neoinstitucionalismo da ciência política. Revista Brasileira de Ciências Sociais. [online], v.23, n.68, pp. 53-71, 2008.

PESSOA NETO, José Antônio Pessoa; CORREIA, Marcelo Bruto da Costa. Comentários ao Regime Diferenciado de Contratação: uma perspectiva gerencial. Curitiba: Negócios Públicos, 2015.

REZENDE, Flávio da Cunha. A "Nova Metodologia Qualitativa" e as Condições Essenciais de Demarcação entre Desenhos de Pesquisa na Ciência Política Comparada. Política Hoje, [s. L.], v. 20, n. 1, pp. 218-252, 2011.

ROSILHO, André Janjácomo. Qual é o modelo legal das licitações no Brasil? As reformas legislativas federais no Sistema de contratações públicas. Dissertação de Mestrado. Fundação Getúlio Vargas, 2011.

SCHMIDT, Vivien A.; RADAELLI, Claudio M.. Policy Change and Discourse in Europe: Conceptual and Methodological Issues. West European Politics, London, v. 27, n. 2, p.1832010, 2004.

SCHMIDT, Vivien A. Discursive Institutionalism: The Explanatory Power of Ideas and Discourse. Annual Review Of Political Science, [s. L.], v. 11, p.303-326, 2008.

SEWELL, William. A Theory of Structure: Duality, Agency and Transformation. American Journal of Sociology, Chicago, v. 98, p. 1-29, 1992.

SHEINGATE, Adam. Political Entrepreneurship, Institutional Change, and American Political Development. Studies in American Political Development, Cambridge, v. 17, p. 185-203, 2003.

SUNDFELD, Carlos Ari. Direito Administrativo para Céticos. São Paulo: Malheiros, 2014.

Prefácio à obra Comentários ao Regime Diferenciado de Contratação: uma perspectiva gerencial. Curitiba: Negócios Públicos, pp. 17-18, 2015. 